Historic, Archive Document

Do not assume content reflects current scientific knowledge, policies, or practices. 



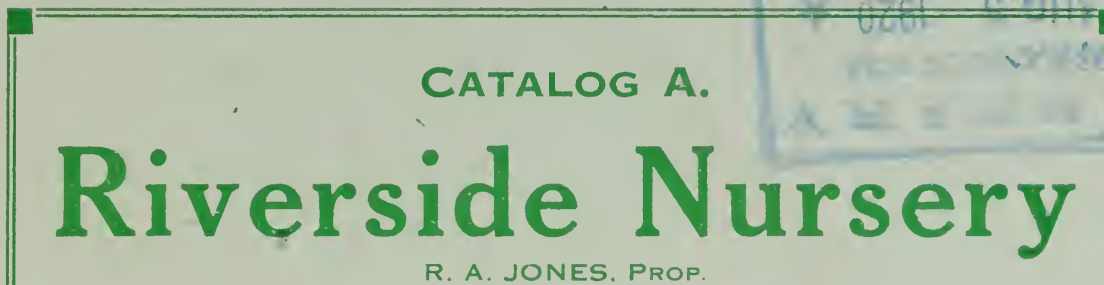

R. A. JONES. PROP

\section{CATALOG AND PRICE LIST OF FRUIT a ORNAMENTAL TREES, ROSES, SHRUBS, Etc.}

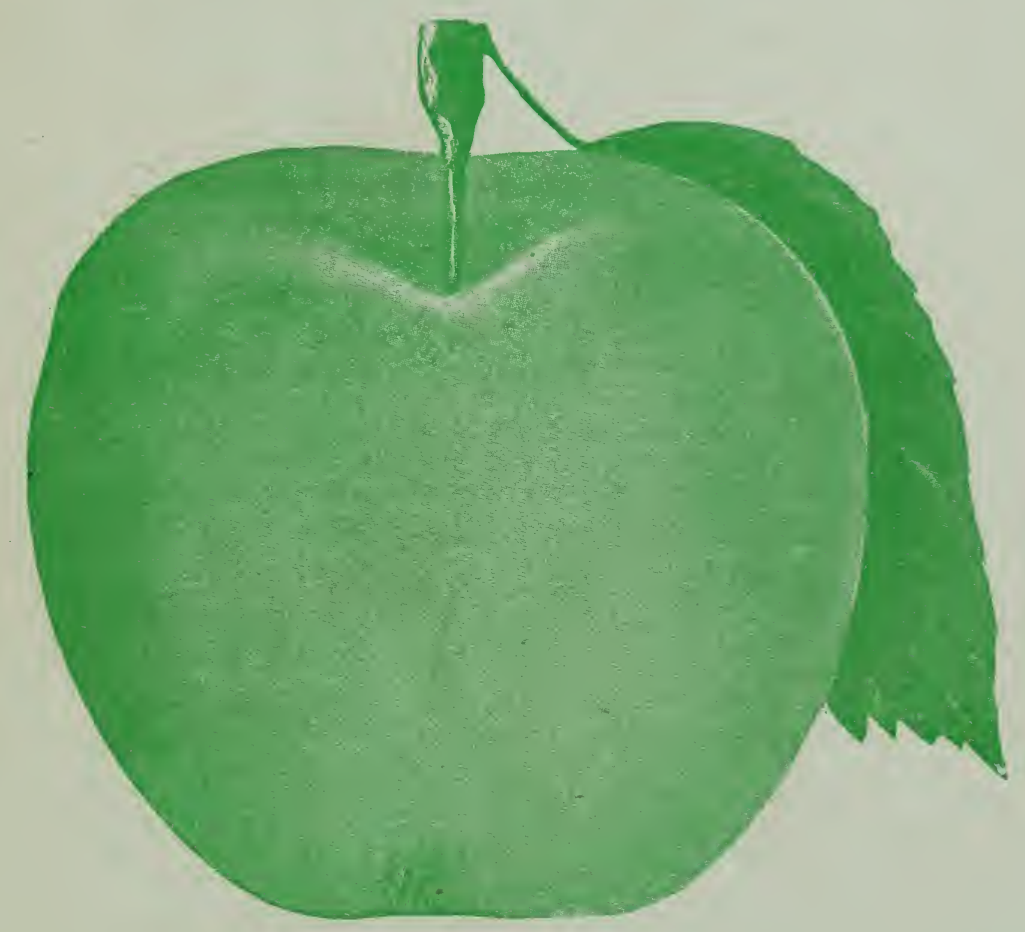

TREES THAT GROW

FRUITS THAT BEAR

\section{Grand Specialty: Genuineness}

STOCK IS PROPAGATED FROM TREES OF HIGHEST FRUITING POWER

ADDRESS ALL COMMUNICATIONS TO

R. A. JONES, Hillyard, Washington, R. F. D. No. 1 


\section{To Our Customers}

\section{Please Read Carefully}

\section{GUARANTEE OF GENUINENESS.}

Genuineness is our specialty, and we exercise the GREATEST CARE to have all stock true to name, and it is mutually agreed between the purchaser and ourselves that our guarantee of genuineness shall in no case make us liable for any sum greater than that originally paid for the stock that nay prove untrue, or we wlll give two trees for every. one that is wrongly named.

\section{ROOTS.}

Our trees have the best roots to be found anywhere, and are whole roots. This is very important, and makes our trees worth much more than the general run of nursery stock from other nurseries. Our trees and shrubs are grown and acclimated here and are much better than stock shipped from abroad.

\section{TERIMS.}

Cash with orders. Send money by Registered Letter, Money Order, Bank Draft or Express. No stock sent C. O. D. We will book orders ahead if half cash is sent with the order, balance to be sent when stock is ready for shipment. Send money orders on Spokane.

\section{SHIPPING DIRECTIONS.}

Be sure to give plain shipping directions and sign your name plainly. All trees, etc., delivered free to any part of the City of Spokane, or railroad depot at Spokane. Except in the City of Spokane, orders must amount to $\$ 3.00$ or more to insure prompt delivery. Smaller orders may be delivered if convenient and in the vicinity of other deliveries.

\section{NO INSECT PESTS.}

Our stock is all free from insect pests; no San Jose Scale; no Wooly Aphis or other dangerous pests.

\section{SUBSTITUTES.}

Sometimes we may be out of the kinds ordered, and in such cases we request our customers to state in their order whether to fill the order with other kinds or not. We never substitute without orders.

\section{EXTENT OF OUR GUARANTEE.}

After stock leaves our hands our liability ceases. When we fill an order the trees are dug fresh from the ground, in good health, and carefully packed; but there are so many things which may cause a tree to fail which are entirely out of our control and not our fault, that we cannot give any guarantee that the trees will live, but we do guarantee our stock to be in good condition when it leaves our hands.

\section{PLANTING DIRECTIONS.}

Dig a hole larger than the roots, pulverize the soil well, and shake it from the shovel thinly and evenly. See that the roots are carefully spread out and straight, and be sure that all roots have a good earth contact. Cut off all smashed or badly damaged roots, above the damaged place. Cut back the tops one-half to two-thirds. If possible, use a half pail or more of water to wash rhe earth perfectly among the roots while filling in and finish at the top with ordinary dry soil or muleh to prevent baking. Do not plant more than three mehes deeper than the tree stood in the nunsery. Cultivate or harrow your orchard every two weeks from early spring until September 1.

Do not take a large number of trees to the field for planting and let them lay exposed to wind or sun. It is best to heel the trees in the earth (that is to eover the roots) near where they are to be planted, and when you plant take out only a few at a time. 


\section{ORDER EARLY}

"The early bird gets the worm." "The first come the first served." Orders are booked as they are received. If possible, send your orders now. Don't wait until spring and get delayed in the rush. We often run short of stock before the season eloses, and then many orders can only be partly filled. Always say whether we ean substitute or not.

\section{FREIGHT CHARGES.}

The ordinary freight charges on fruit trees are from 1 to 2 cents per tree for distances up to 150 miles from Spokane. Nearer by will be less, farther away a little more. Small bundles not weighing over 50 or 75 pounds should be sent by express, which costs but little more than freight.

We do not prepay freight except where freight money is sent with order to pay the charges. In towns where there is no freight agent, freight moneyshould always be sent with order.

\section{INSPECTION.}

Much damage is often done to nursery stock as a result of inspection. Bundles are opened and often are tied together again so poorly that the roots are exposed to sun and air, and hauled many miles in this condition. In such cases the best trees ever grown cannot be expected to succeed well. It often means the death of the stock and we eannot be blamed for trees failing to grow that bave been thus treated.

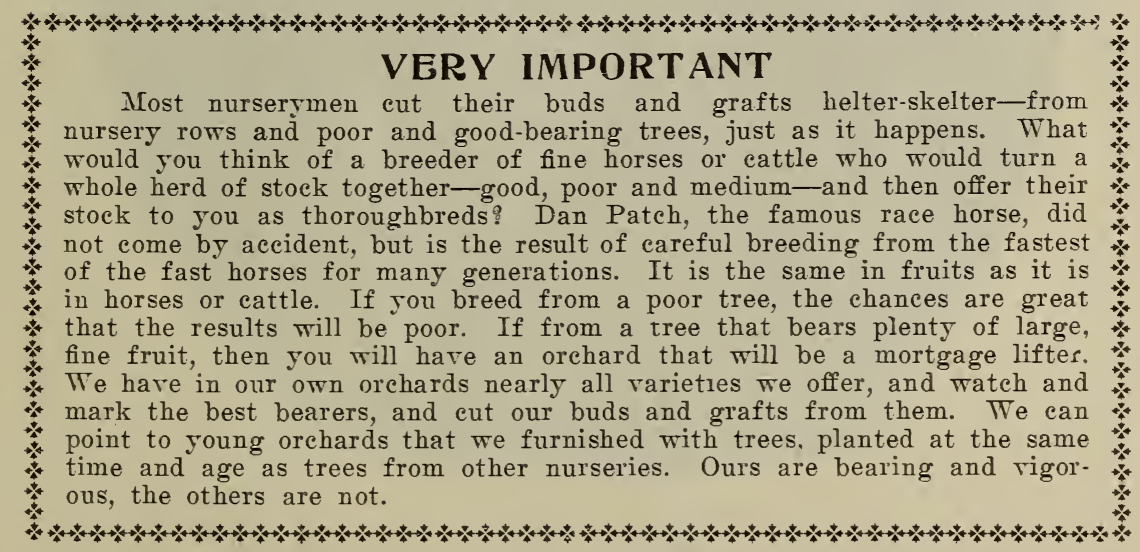

\section{APPLES}

\section{Summer and Autumn Varieties}

DUCHESS-The best late summer apple, large, striped red, rery hardy, great bearer.

FALL PIPPIN-A very large and excellent fall and early winter apple. Color greenish yellow.

RED JUNE-An excellent summer table apple; beautiful red. Ripens from August to September.
TRANSCENDANT CRAB - The best crab ever introduced. August to September.

WEALTHY-In Montana this is one of the best winter apples, very hardy, a great bearer, rich red, juicy and fine. October to December.

RED ASTRACHAN-Large, beautiful deep red, good cooker, and rer: hardy. Season August.

JEFFERIES-An excellent and beautiful apple. Good size, striped red and 
yellow, splendid quality. Season, October to November.

YELLOW TRANSPARENT - Mediumı size, color ereamy white, fine quality, very early.

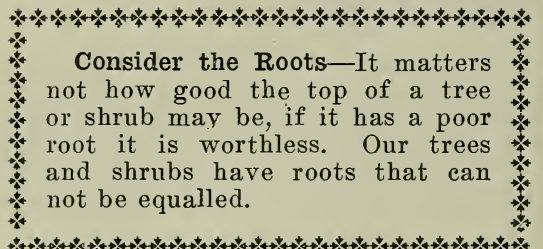

dark red, handsome and a long keeper, good quality. Season, March to April. None to offer this spring.

BALDWIN-Excellent, large, red, an old stand-by. January to March.

BAILEY SWEET-The most beautiful sweet apple grown. Large, rich, deep red; excellent quality. Season, November to January.

ESOPUS SPITZENBURG - Excellent but a moderate bearer; an apple of the highest quality and always commands the highest market price. February to March.

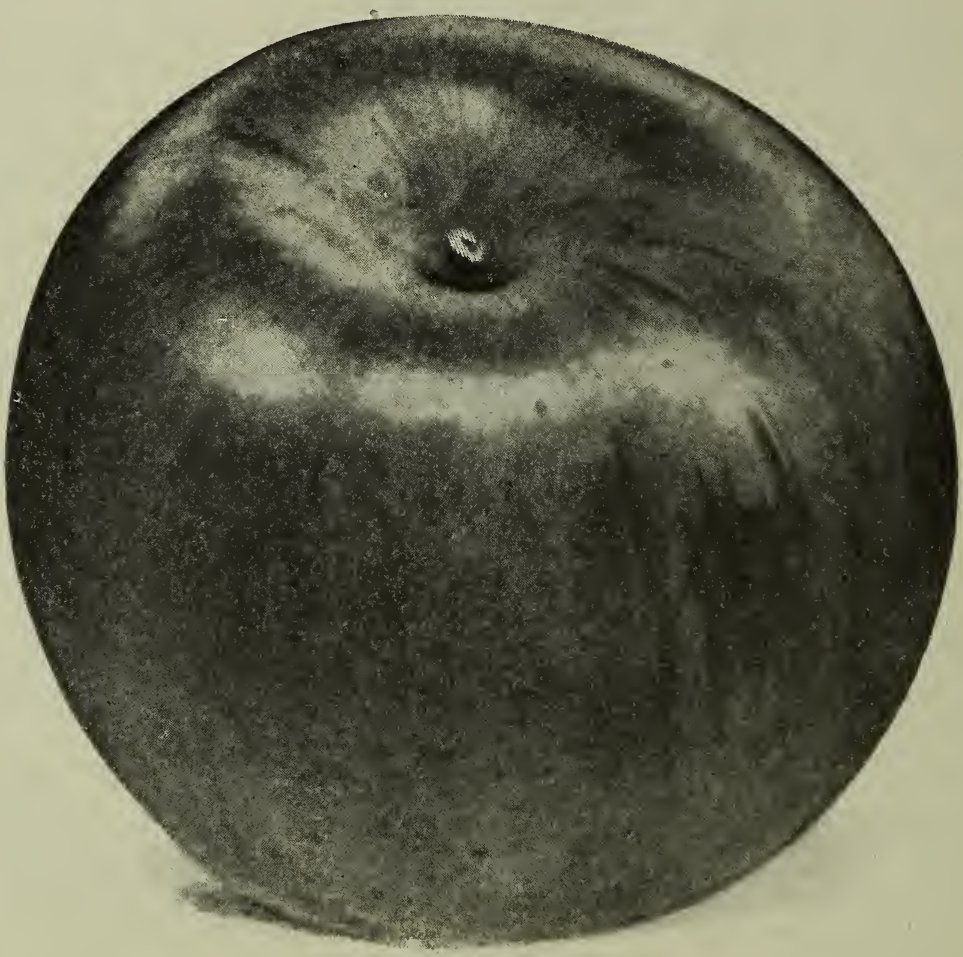

ROME BEAUTY.

GRAVENSTEIN-The best apple of its season, and is not surpassed by any apple of any season. Beautiful yellow and red. Season, September and Oetober.

MIIDEN'S BLUSH-Good size, yellow with red cheek, beautiful and excellent. Season, September.

\section{Winter Varieties}

ARKANSAS BLACK - Large, very
FAMUSE (Snow) - Very fine, medium size, beautiful red; one of the best eating apples. October to December.

RHODE ISLAND GREENING-Superb; succeeds well almost overywhere; strong grower and great bearer; large. January to March.

HOOVER-A very beautiful dark red winter apple. A good seller, good keeper and good quality.

GRIMES GOLDEN-Good size, yellow. 
of highest quality, and very productive. January to April.

JONATHAN-One of the best; good keeper, great bearer and splendid market apple, medium size, crisp, juicy, extra quality, color bright, rich red, great bearer, but fruit must be thinned to obtain good size. December to January.

KING-One of the largest and most beautiful apples ever produced; rich red and yellow, excellent quality. Norember to January.

MeINTOSH RED-Large, bright red; sub-acid; very good and handsome; vigorous and hardy. November to February.

NORTHERN SPY-Tery fine, an old farorite for home use and in many places a great market apple; large size; color red and green. December to March.

OPALESCENT-Claimed by its introducers and all ways considered the apple without an equal. Large size, beautiful red, takes a high polish, excellent quality, long keeper, great bearer. and rery hardy. What more could be desired? Tre advise all to try it. Stock scarce. Only one tree will be sold in each order. Price, 50 cents each.

POUND SWEET-An old, well-known and superb sweet apple. The kind that our grandfathers used to grow. Large, vellow and very sweet. Season, November to Warch.

ROME BEAUTY-Probably the most popular market apple in the Inland Empire, and is being extensively planted; very large, beautiful and good; color beautiful rich red; keeps till March or April. (See cut.)

SPOKANE BEAUTY-A new apple of immense size, originated near Walla Walla; cosor vellow, mostly corered with red; good quality, good keeper and good bearer.

SWEET BELLFLOWER (Delicious)A fine new apple of Bellflower type. Color red; flavor sweet and of very high quality. Season, December to May. Scarce.

WAGENER-Another market "crackerjack,' early and abundant bearer. high quality, long keeper, large size, red and vellow. January to April. Wagener stock nearly gone. Not more than 10 will be sold to same person. Next fan will have a large stock of this famous apple.
ITINTER BANANA-A vigorous grower and early bearer. Fruit large and handsome, creamy white with beautiful red cheek and of best quality. Season, January to March.

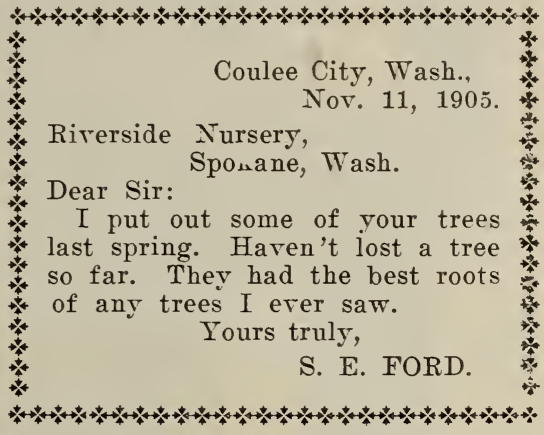

WOLF RIVER-Very large; color beautiful red. One of the greatest show apples. Every one should have a tree or two. Season, October to January.

WISMER:S DESSERT-A new apple from Canada. Said to be the best table apple ever produced. Good size. handsome color, great bearer, and very hardy. Season, January to Mareh.

WINESAP-One of the greatest market apples grown along the Columbia river and its tributaries. Large, deen red, fine quality, Jong keeper, and great bearer. It seldom does well on altitudes above 1500 feet in the Inland Empire. Season, January to April.

YELLOW NEWTOWN or ALBEMARLE PIPPIN-Best long-keeping winter apple, but will flourish only in certain districts and soils. It attains great perfection in many localities in the Inland Empire. It ranks among the highest in quality and commands the highest price in foreign markets. It retains its high quality, even into summer.

YELLOW BELLFLOWER-An old. well-known and excellent apple. Large, yellow, fine quality. Season, November to January.

\section{PRICES OF APPLE TREES}

Two years old Per First size -5 to $6 \mathrm{ft} \quad \$ .20 \quad \$ 18.00$ Second size-t to $5 \mathrm{ft} . . . . . . . .18 \quad 15.00$ $\begin{array}{llll}\text { Third size }-3 \text { to } 4 \mathrm{ft} \ldots \ldots \ldots \ldots . . . & .15 & 12.00\end{array}$ One year-216 to $3 \mathrm{ft} \ldots \ldots . . . .150 .150$ 25 or more of a kind will be sold at 100 rates. 


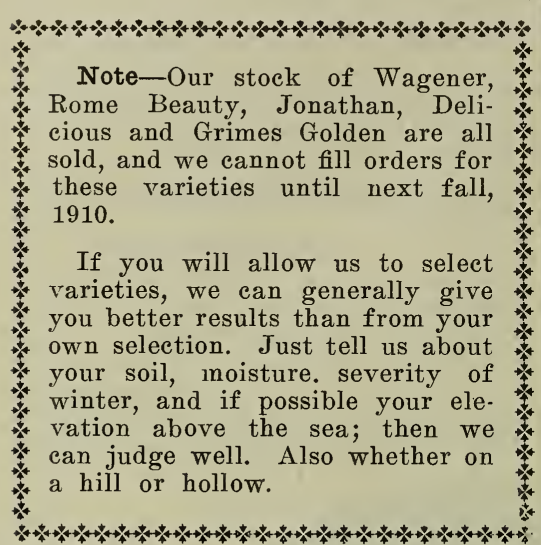

PEARS

ANJOU-Probably the best pear in eul tivation. November to January.

BARTLETT-One of the best-known and popular pears. September.

FLEMISH BEAUTY-One of the most beautiful of all pears, good quality, large, good bearer. October.

SECKEL-An old, well-known pear of small size. It is still regarded as the most delicious pear in cultivation.

Most all pear trees have poor
roots; but ours have exceptionally
good ones, and will live and
thrive where others fail.

PRICES OF PEAR TREES

First Class-Two Year

6 to $7 \mathrm{ft}$.....................................50 each

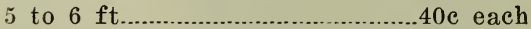

4 to $5 \mathrm{ft}$.....................................30e each

3 to $4 \mathrm{ft} ., 1$ year..............................20 each

\section{CHERRIES}

\section{Sweet Varieties}

BING-Very large, black, excellent quality. Season medium.

LAMBERT-Of largest size and best quality; color black; very firm; good shipper. Late.

ROYAL ANN-The largest light-colored sweet cherry; yellow and red; very popular and good.

\section{Sour Varieties}

LATE $\nu$ UKE-The best late red cherry; large and delicious; fine for pies and canning.

MAY DUKE-The best early red cher- ry; great bearer; much used for pies and canning.

MONTMORENCY - The best red sour cherry of its season; 10 days later than May Duke. Very hardy and productive; far ahead of Early Richmond, being much larger and better. Every home should have it.

OSTHEIMER-A very late dark red cherry, similar in flavor to Eng. Morello. It is the hardiest in tree and fruit bud, and also the greatest bearer we have ever seen.

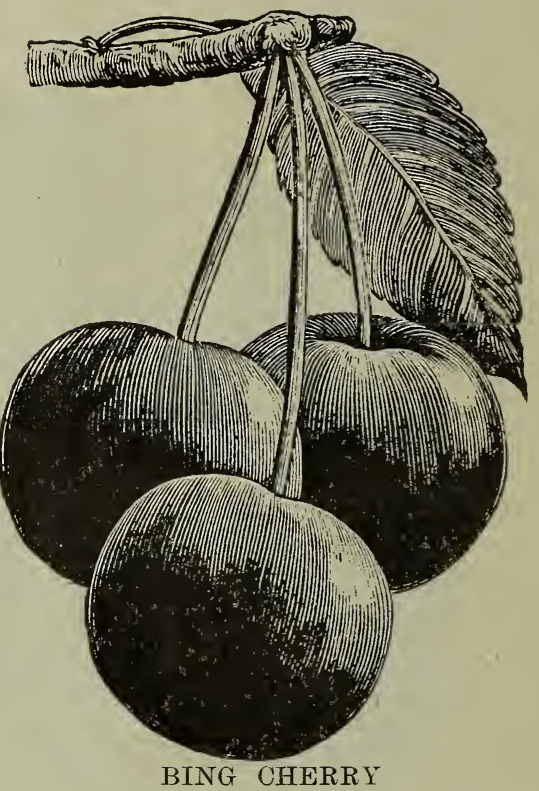

PRICES OF CHERRY TREES.

Sweet Varieties-One Year.

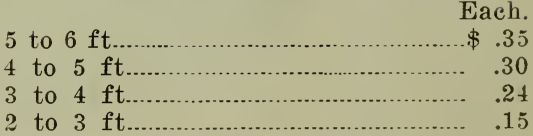

Sour Varieties-One Year.

Each.

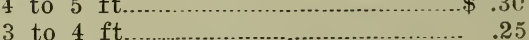

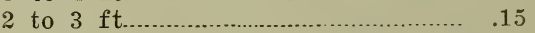

A few Royal Ann, Lambert, Montmoreney and Ostheinier 2 years old at 50 cents to $\$ 1$ each, according to size and quality.

\section{PEACHES}

ALEXANDER-The most popular of all early peaches; very hardy and prolific; clingstone; color mostly covered 


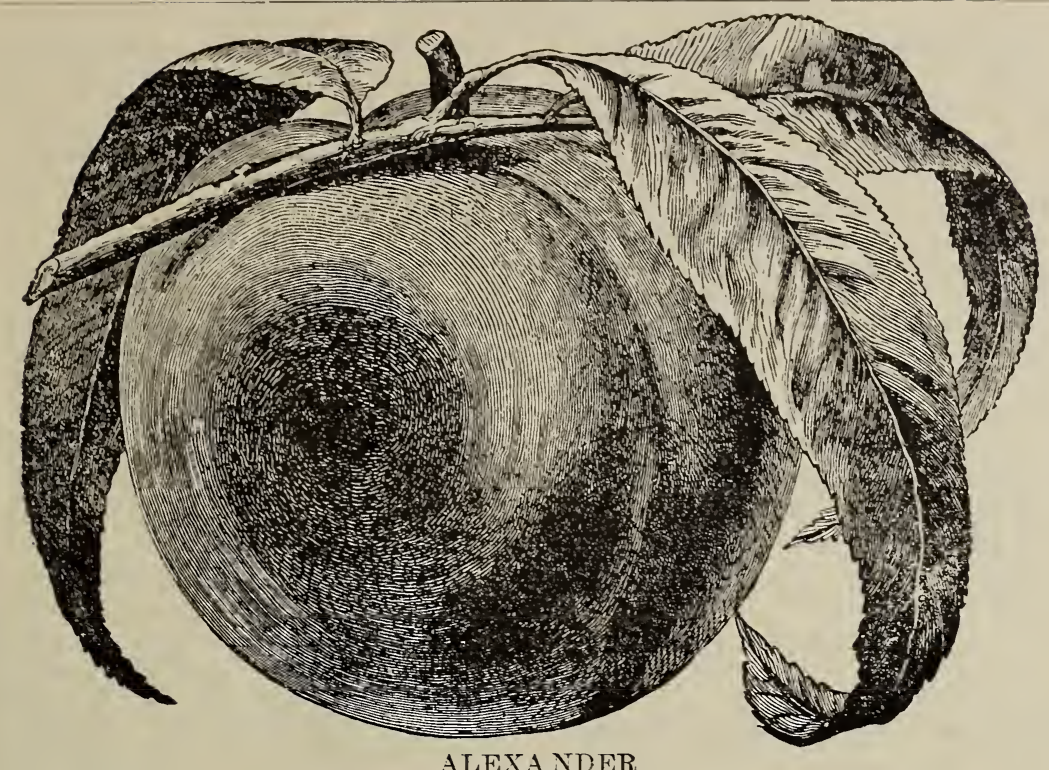

with red; every one should have it. Season, August 1.

ELBERTA-Very large, yellow, with red cheek; a great market peach; freestone. September.

EARLY CRAWFORD-Probably the most popular peach in cultivation; of large size; red and yellow; freestone; of high quality. Season, September 15 .

TRIUMPI-A large, fine early peach; beautiful deep red; free when fully ripe; hardy and great bearer. July and August.

PRICE OF PEACH TREES

$\begin{array}{rr}\text { Per } \\ \text { Each. } & 100 .\end{array}$

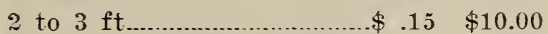

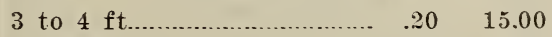

4 to $5 \mathrm{ft} \ldots \ldots \ldots \ldots$

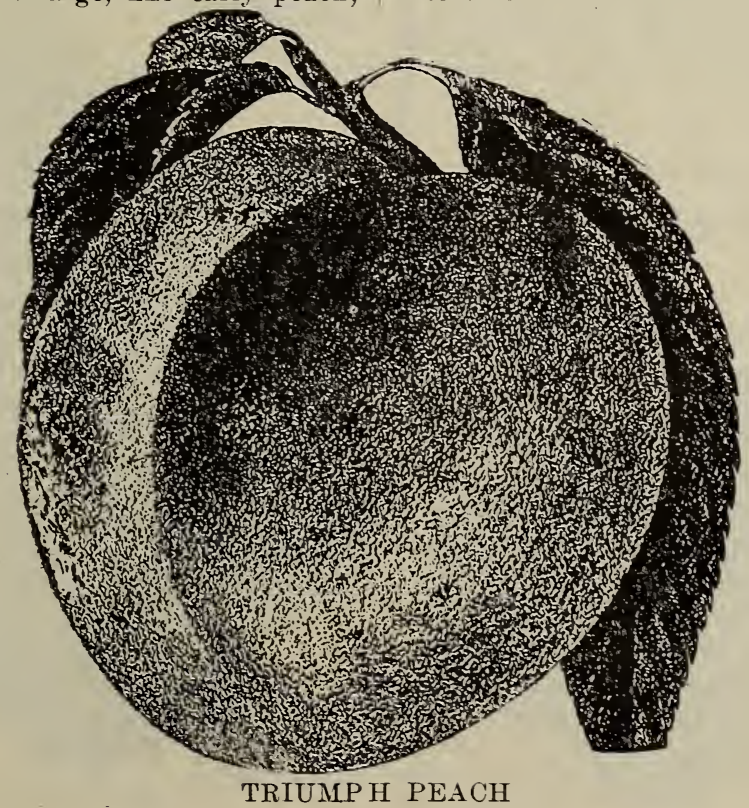




\section{PLUMS AND PRUNES}

PEACH PLUM-Large, early, red; one of the very best. July and August.

ITALIAN PRUNE-A sweet, excellent fruit; should be in every collection; large, dark purple. September. This is the best all-around prune in general cultivation.

HUNGARIAN PRUNE-Very large, dark red, juicy and fine.

YELLOW EGG-A very large, egg. shaped plum of fine quality. Sep. tember.

BRADSHA W-Very large, purple; ripe between peach and egg plums; fine quality.

('LIMAX -A splendid large early Jap. plum, by Luther Burbank; beautiful red and yellow color.

SATSU $r$ A-A very good Japanese plum, with blood-red meat and dark red skin.

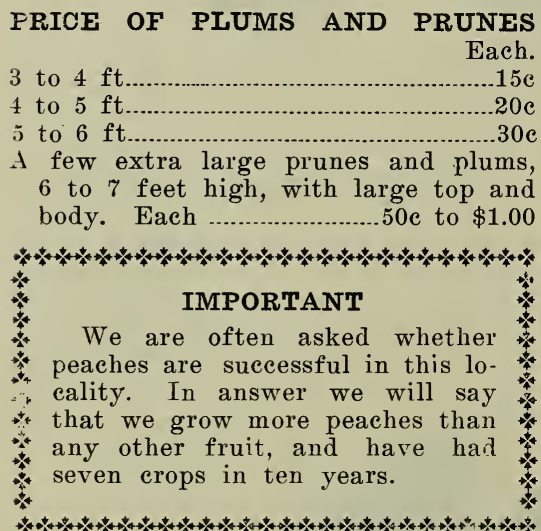
APRICOTS

$S[T P E R B-T h i s$ variety excels in quality as well as in hardiness and productiveness. It has large, beautifully colored fruits, with rich, sweet and mealy golden yellow flesh; averages better in size and quality than any other apricot and bears more constantly. Price, each.

\section{BLACKBERŔIES}

RATHBUN-Very large, good bearer; strength of growth medium; extra fine quality and quite hardy. (See (cut.)

SNYDER-Of all blackberries, this is probably the best. It is very hardy, great bearer, immense canes, and fine, sweet berries; no hard core. Berries are not large, just medium size, about $3 / 4$ inch long. We recommend it as the best all-round berry that we have. The Lawton Blackberry will not stand the winters here.

\section{PRICES OF BLACKBERRIES}

Snyde:-10c each, 15 for $\$ 1.00,100$ for $\$ 4.00$.

Rathbun-10e each, 12 for $\$ 1.00,100$ for $\$ 5.00$.

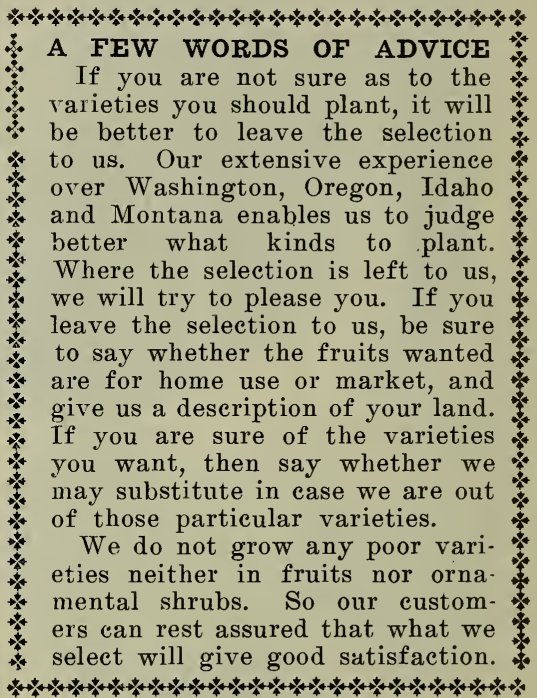

\section{LOGANBERRY}

LOGANBERRY-A new and very valuable fruit. A cross between the blackberry and raspberry. In size

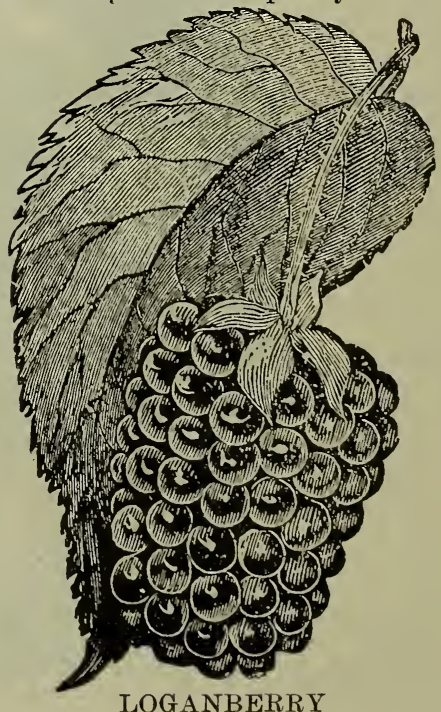


they look like immense blackberries, with deep red color. Every one should have them; excellent for sauce, pies and canning. Price $10 \mathrm{c}$ each, $\$ 6.00$ per 100. Two-year, very large, $25 \mathrm{c}$ each. (See cut.)

\section{DEWBERRIES}

LVCRETIA-This is the best kind; we offer no other. The dewberry is a great bearer of sweet, fine berries resembling blackberries, but are larger and better. They are great moner makers. One grower at Greenacres cleared about $\$ 600$ per acre from dewberries. Price, 10c each, $\$ 5.00$ per 100 . Two-year large plants, 1 čc eacn, $\$ 10.00$ per 100 .

\section{RED RASPBERRIES}

('UTHBERT-Red, the old standard. Prices: Each, 5c; per 100, $\$ 4.00$.

COLUMBIAN-Red immensely productive and very hardy; berries very large and of high quality; 10c each, $\$ 5.00$ per 100 .

LOUDON-Another very productive, large and excellent berry, one of the hest. We recommend this and the above one as exceptionally fine. Prices: $10 \mathrm{c}$ each, $\$ 5.00$ per 100 .
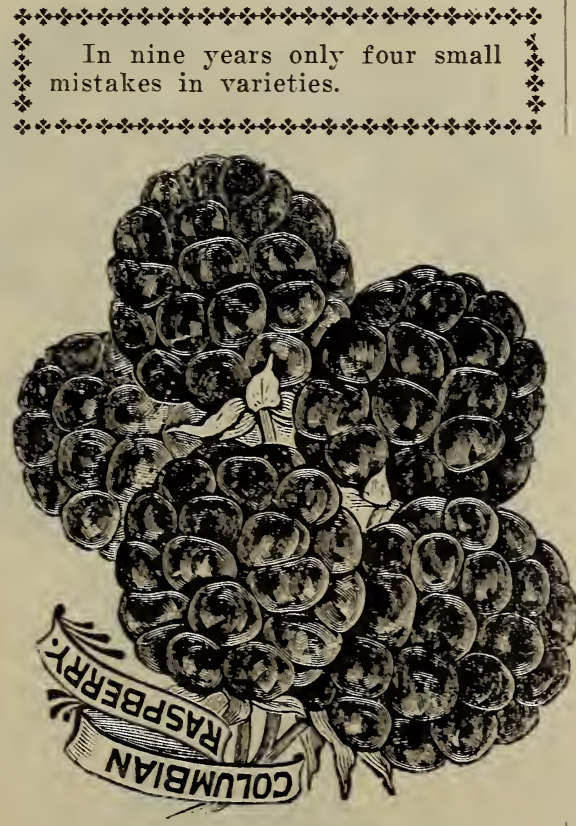

BLACKCAP RASPBERRIES

KANSAS-A very hardy and drouth resisting kind. Berries large, and a great bearer; best quality. The best all around blackeap, and we offer no other. Prices: $10 \mathrm{c}$ each, $\$ 5.00$ per 100 . Two-year, extra fine, 20c each. $\$ 10.0$ () per 100.

\section{CURRANTS}

FAY'S PROLIFIC-The largest and best red currant.

BLACK VICTORIA-An old famou: English variety.

\section{PRICES OF CURRANTS}

One year, each......................................10c

Two year, each...................................

Extra large.........................................25c GOOSEBERRIES

We offer but one gooseberry, the OREGON CHAMPION, which seems to be giving satisfaction most everrwhere. It is large and fine and a good bearer. Price $15 \mathrm{c}$ each, $\$ 12.00$ per 100 .

\section{STRAWBERRIES}

HOOD RIVER-Season early.

GLEN MARY-Season early to late. and a great bearer.

WM. BELT_-Season late; extra quality. HUNN-A new berry of immense size. very beautiful and good. Every one should try it.

GANDY-Season late. Great market berry.

TAN DEMIAN-Season early.

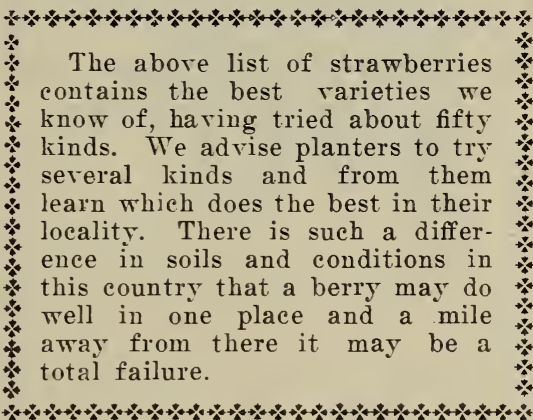

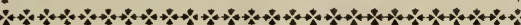

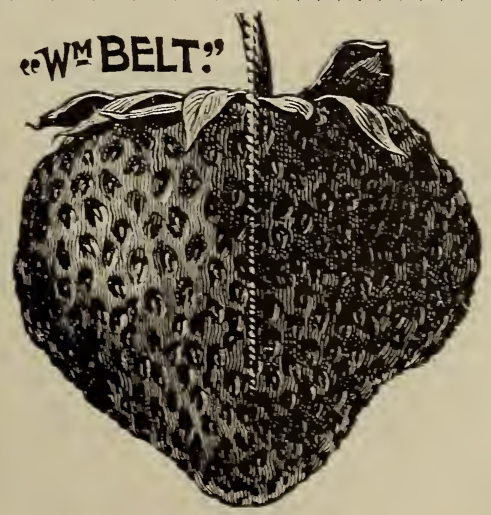




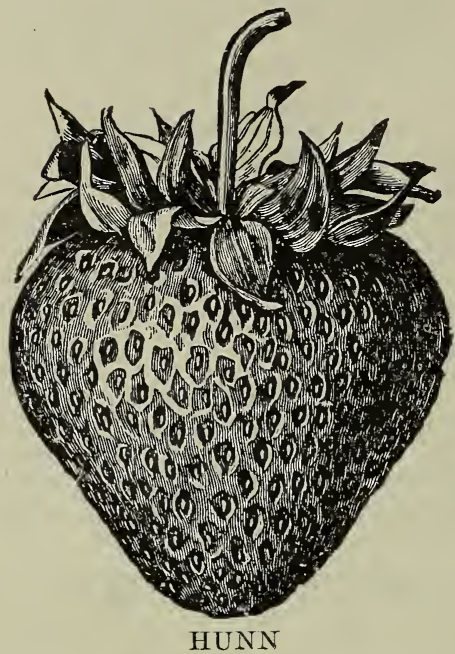

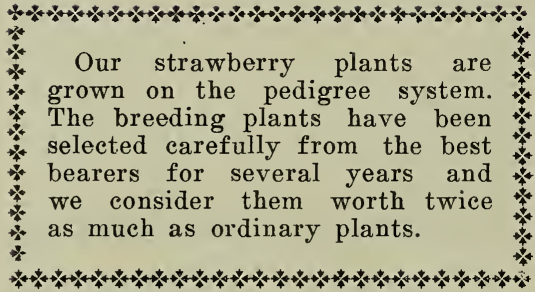

\section{PRICES OF STRAWBERRIES}

Per dozen ............................................ .25

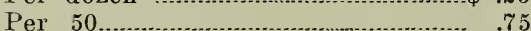

Per $100 \ldots \ldots \ldots$

Per $200 \ldots \ldots . . . . . . . . . . . . . . . . . . . . . . . . . . . . . . . . .2 .00$

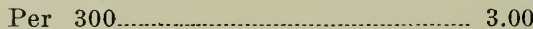

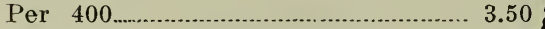

Per $500 \ldots \ldots \ldots \ldots$

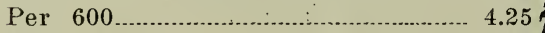

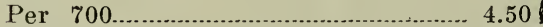

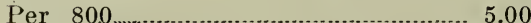

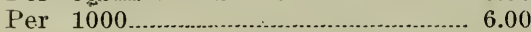

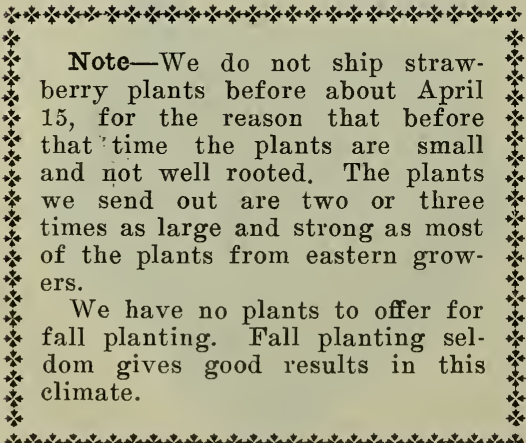

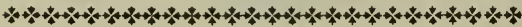

\section{GRAPES}

CONCORD-Black; well known everywhere; one of the best.

MOORE'S EARLY-Black, large, early.

LIAMOND-White, fine, sweet, early, prolific.

The above varieties are among the best for this locality.

\section{PRICES OF GRAPES}

Two-year, 15c each, 8 for $\$ 1.00, \$ 10.00$ per $100, \$ 80.00$ per 1000 .

Our vines are extra fine and have immense roots.

ASPARAGUS-Per dozen $\$ .25$

Per 100 1.00

RHUBARB (Pieplant)-Each........ \$ .10

Per dozen 1.00

Extra large .25

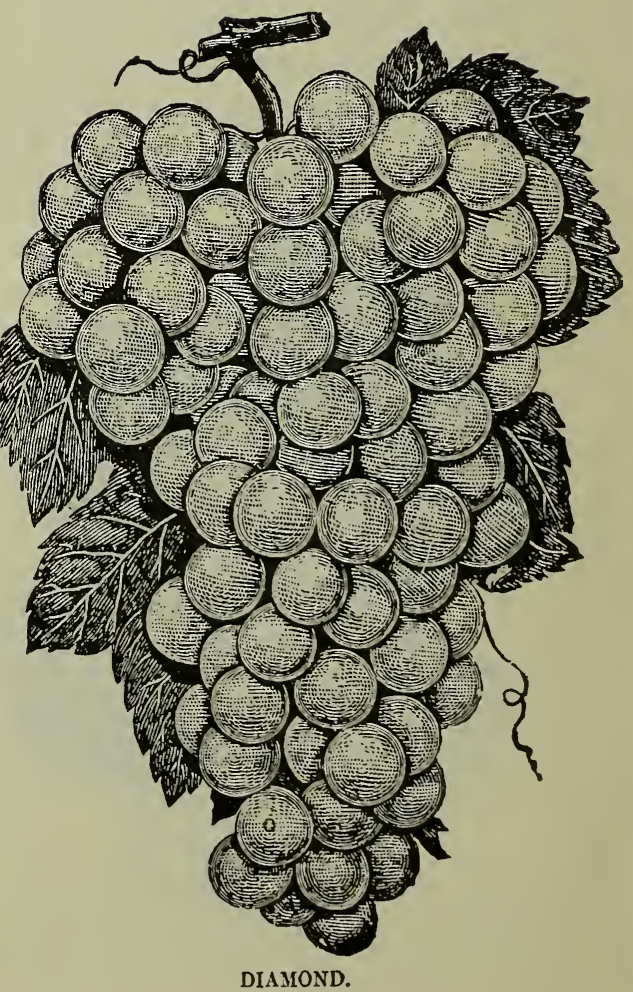




\section{Hardy Shade and}

ASH

ASH (Flowering)-An American species of rapid growth, forming a beautiful tree; its flowers are also quite attractive.

$\tau \mathrm{ft}$, to $9 \mathrm{ft}$., each...........\$1.00 to $\$ 1.50$

AMERICAN BEECH-Well known. Small trees about 6 feet high.

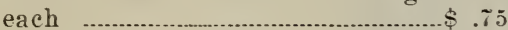
9 to 10 feet. each............................ 2.00

PLRPLE BEECH-Beautiful purple foliage all summer. It makes a fairsized tree in time and contrasts fine with other trees, especially golden foliage.

Price, 4 to 5 feet, each.

$\$ 2.00$

\section{BIRCH}

CUT LEAF TEEPING BIRCH-The nost beautiful of all weeping trees. Sniall trees, 6 feet high, each...... \$1.00 s feet, each .................................... 1.50 10 feet, each …................................ 2.50

EUROPEAN WHITE TEEPING BIRCH-A rers rapid growing tree, and seems to do well everrwhere; beautiful silvers white bark and after a few rears assumes a graceful reeping habit.

Trees 6 feet high, each.................... \$ .50

8 feet high, each......................... 1.00

Extra fine, 10 feet high. each...... 2.00

SEA BUCKTHORN-A small size, compact tree with silvers foliage; bearing profusely small. bright orangered berries, which hang all winter. Good for poor. sandr soil, and is rerr hardy. Prices:

3 to $4 \mathrm{ft}$. each $\ldots$

4 to $5 \mathrm{ft}$. each.

6 to $r \mathrm{ft}$. each

\section{BUTTERNUT}

BLTTERNLT-A well-known American tree, similar to the walnut. It makes a fairls rapid growth and bears excellent nuts. Prices:

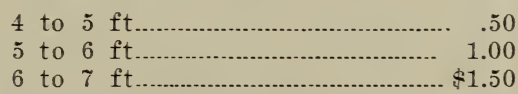

CATALPA SPECIOSA-Hardr or Test ern Catalpa. A rapid growing tree, with large leares and large pinnacles of flowérs in midsummer. Price:

5 to $6 \mathrm{ft}$., each................................ \$ .50

6 to $\tau \mathrm{ft}$., each.................................. .75

8 to $9 \mathrm{ft}$., each. hears. $\$ 1.50$ to $\$ 2.00$

AMERICAN CHESTNUT-The fine old chestnut that is well known to most Eastern people succeeds woll here. They are fairly rapid growers. Price:

\section{Ornamental Trees}

3 to $4 \mathrm{ft}$, each $\ldots \ldots \ldots \ldots \ldots \ldots \ldots \ldots \ldots \ldots \ldots \ldots \ldots \ldots \ldots \ldots \ldots . . .50$

4 to $5 \mathrm{ft}$, each

$6 \mathrm{ft.}$, each....................................... 1.00

"HESTYUT (Spanish) - The bare found this to bear better than the American, and it is a more beautiful tree. Price: $2 \mathrm{ft}$., each....................................... 3 to $4 \mathrm{ft}$, each................................ .50

4 to $5 \mathrm{ft}$, each............................. 1.00

BECHTEL DOUBLE ROSE FLOTER ING CRAB-A very beautiful ornamental tree, loaded in Miay with large, flesh-colored double flowers with delightful riolet fragrance. The flowers

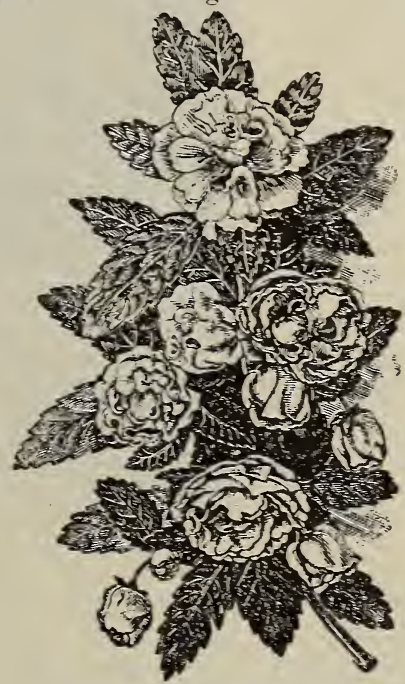

BECHTEL DOUBLE ROSE FLO WERING CRAB.

1/4 Natural Size.

appear after the leares are rell out and make a beautiful contrast. The tree is rers hardy. (See cut.) Prices:

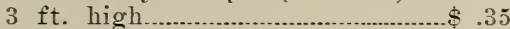

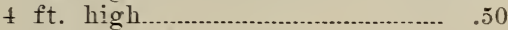

$5 \mathrm{ft}$. high, fine top........................ 1.00

$6 \mathrm{ft}$. high, extra fine....................... 1.25

Extra fine specimens....................... 2.00

FLOTERING CRAB. ATROSAN. GIUNNEA-A tree with beautiful crimson flowers in May, in great profusion. Price:

4 to $5 \mathrm{ft}$, each................................. $\$ . \tau$

FLOTERING CRAB. FLORIBUNDAA small tree with immense quantities of pink and white flomers in May, and rery ornamental fruit in autumn. Price:

4 to $5 \mathrm{ft}$, each..................................... . 


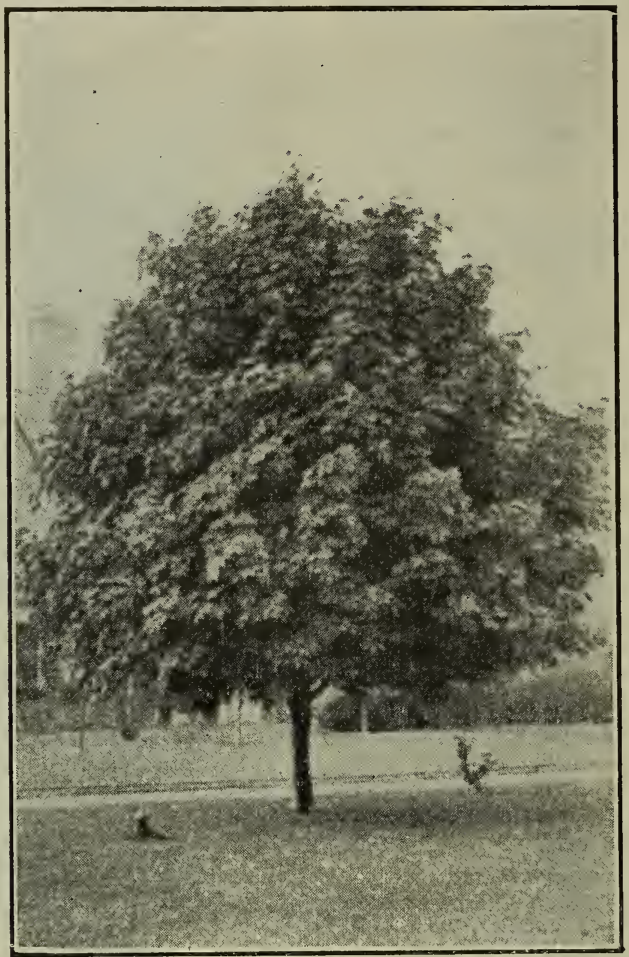

HORSE CHESTNUT

TI.OWERING CRAB. MEDWIETGUINEA-A tree with beautiful flowers; fruit is of a dark red color. Very unique and pretty. Price:

6 to $7 \mathrm{ft}$., each..

$\$ 1.00$

\section{ELIM}

CAMPERDOWN WEEPING ELMThis is the tree seen in lawns with broad, umbrella-like tops and large leaves. They are very attractive. Price:

6 to $7 \mathrm{ft}$., 1-year heads, each.... $\$ 1.00$

6 to $7 \mathrm{ft}$., 2-year heads, each... 1.50

CORK ELM-A unique looking tree, with corky bark; is doing well here.

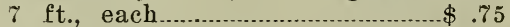
$8 \mathrm{ft}$. to $10 \mathrm{ft}$., each....................... 1.50

ENGLISH ELM-A fine elm that is not attacked with curl ]eaf; compact and symmetrical, and a fast grower. $7 \mathrm{ft}$. $\$ .75$

$8 \mathrm{ft}$, heavier, each. 1.00 Larger sizes, special prices.

WICH ELM-The best elm yet tested in this country; very rapid grower and large leaves; free from curl leaf.
$8 \mathrm{ft}$. each $\$ .75$

$10 \mathrm{ft} .$, heavy and fine....\$1.25 to $\$ 1.75$ $12 \mathrm{ft}$., extra, $21 / 2$ to 3 in., $\$ 2.50$ and up HORSE CHESTNUT (White)-

$4 \mathrm{ft}$., each. $\$ .50$

5 to $6 \mathrm{ft}$., each................................. 1.00

7 to $8 \mathrm{ft}$., each............................... 1.50

\section{HAWTHORN}

DOUBLE WHITE HAWTHORNSame as Paul's, but white. Prices same.

PAUL'S DOUBLE RED FLOWERING HAWTHORN-One of the most beautiful of all ornamental trees; very hardy and resists drouth well; bright, double red flowers in clusters, profusely ${ }^{*}$ scattered amongst the deep green foliage in June.

Small trees, 3 to $4 \mathrm{ft}$. high, each..\$ .50 4 to $5 \mathrm{ft}$. high, each.................. 1.00 $6 \mathrm{ft}$. high, very fine, each........... 1.50 7 to $8 \mathrm{ft}$., extra fine, each....\$2 and up WHITE ENGLISH HAWTHORNThe famous English hedge plant; makes a fine small tree also. It bears bright red berries, which hang 
on the trees all winter. It deserves more attention.

$3 \mathrm{ft}$. $\$ .25$

$4 \mathrm{ft}$. .50

$6 \mathrm{ft}$.

$7 \mathrm{ft}$., bearing size

1.00

KOELRELTERIA-A fine, small growing tree from Japan, with luxuriant. fern-like foliage.

$5 \mathrm{ft}$. , each

$\$ .50$

6 to $\tau \mathrm{ft} .$, each

1.00

1.ABURNUM, OR GOLDEN CHAINI fine oruamental tree from the Highlands of Scotland, with long strings of golden rellow flowers.

$+\mathrm{ft}$., each

$6 \mathrm{ft}$., each

1.00

$s$ ft., each

1.25

I.NDEN-This is the tree we hear so much about being used in the streets of Berlin, Germanr. It is a beautiful tree and makes a silendid shade. The roung twigs are deep red in winter. $6 \mathrm{ft.} 3_{4}^{3}$-in. diameter, each $\$ .50$

$s \mathrm{ft}$. and up, $11 \frac{1}{ \pm}$ to $1 \frac{1}{2}$ in. in diameter, each $\$ 1.00$ to $\$ 2.00$

\section{LOCUST}

YELLOW OR IOMMON LOCUSTi ft., each...................................... $\mathrm{S}$ to $10 \mathrm{ft}$, each........................... 1.00 10 to $12 \mathrm{ft.,} 2 \mathrm{in}$. diameter............ 2.00 We have some at $\$ 2.50 .21 \frac{1}{2}$ to 3 inches in diameter, and 12 to 15 feet high; are straight and extra fine.

HONEY LOCLST-Beautiful fernlike foliage and very hardy. Do not mistake this tree for the common locust. $+\mathrm{ft}$., each $\$ .50$ i ft., each 1.00

MOSS LOCUST (Rose Acasia)-Mossy branches with a profusion of delicately colored pink flowers in June, and at intervals during the summer. Very pretty. Price:

+ to $5 \mathrm{ft}$., each. $50 c$

\section{MAPLE}

BLACK TARTARIAN MAPLE-A medium sized tree. The foliage turns dark red in autumn and is very attractive. Price:

5 to $6 \mathrm{ft}$.. each.

$\mathrm{s}$ to $10 \mathrm{ft}$.. each

1.00

NORWAY MAPLE-6 ft., each......\$ .50 $8 \mathrm{ft}$., each.

$10 \mathrm{ft}$, each.................................. 1.50

PURPLE LEATED NORWAY MAPLE (Schwedleri)-Of all forms of the Norway maple. Schwedleri is the most beautiful. Early in the spring the leares are a deep, rich shining purple, and in summer a dark bronze green.
5 ft., each

$\$ .75$

$7 \mathrm{ft}$., each

9 ft., each

1.50

SOFT MAPLE-Each.

$.50 \mathrm{c}$ to $\$ 1.00$

SCARLET MAPLE-This maple is valued for its bright scarlet blos. soms in early spring, and the gorgeous autumn coloring of its foliage. When the frosts of autumn strike its foliage it assumes the most beautiful shades of scarlet, crimson, orange, rellow and green. It is not suitable for street planting, for it does not grow large enough.

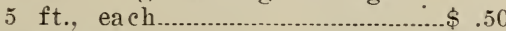

7 to 8 tt., each................................ 1.00

STCAMORE MAPLE- $\tau$ tt., each $\$ .50$ 10 ft., each..................................... 1.00

HARD MAPLE-4 ft., each...........\$. .25 $8 \mathrm{ft.}$ each...................................... .75 $10 \mathrm{ft}$. , each........................................ 1.25

$10 \mathrm{ft}$. heavr

MOLNTAIN ASH (European) - A wa]] known ornamental tree: large clus ters of red berries in autumn.

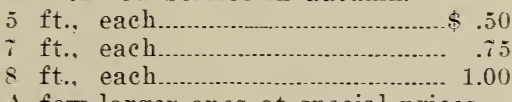

A few larger ones at special prices.

TEA'S TEEPING MULBERRY-One of the finest of small weeping trees. Foliage very ornamental. Price:

4 to $5 \mathrm{ft}$., each........................... \$1.50

RUSSIAN MULBERRY-

3 to $4 \mathrm{ft}$., each....................................25c

4 to $5 \mathrm{ft}$., each..................................... $40 \mathrm{e}$

6 to 7 feet, each.................................75c

\section{OAK}

BTR OAK-A sturdy growing tree with corky bark. Its growth with us is about two feet per year, and it is rery hardy.

$5 \mathrm{ft}$., each......................................... .50

$7 \mathrm{ft}$. e each........................................ 1.00

OAK (Scarlet)-This is the best oak we know of for ornament. Its leares change to a brilliant scarlet in autumn.

$\begin{array}{lll}5 & \mathrm{ft} . \text {, each } & \\ 7 \mathrm{ft} . & \text { each } \ldots \ldots \ldots \ldots \ldots\end{array}$

\section{POPLARS}

BOLIEANA POPLAR-A beautiful tall tree of upright growth, maplelike leaves, dark green above and pure white on under side.

$10 \mathrm{ft}$., each.

CAROLINA POPLAR-This is the best tree for quick growth, shade and wind break: stands drouth better than any other tree. Prices:

Snall sizes, $6 \mathrm{ft}$. per $100 \ldots . . . . \$ 10.00$ 
$7 \mathrm{ft.,} 1$ in. in diameter.................. .25

$8 \mathrm{ft} ., 11 / 4$ in., each......................... .50

$10 \mathrm{ft}$., medium, $11 \frac{1}{2}$ in., each....... 75

$10 \mathrm{ft}$., heavier, each.................. 1.00

10 to $12 \mathrm{ft}$., extra heavy and

fine, $13 / 4$ to $21 / 2$ inches in diame-

ter, each $\$ 1.25$ to $\$ 2.00$

LOMBARDY POPLAR-

8 ft., each...

10 to $12 \mathrm{ft} ., 1 \frac{1}{2}$ in. in diameter, each

SILVER POPLAR-A rapid growing, hardy tree, with beautiful silver foliage.

$6 \mathrm{ft}$., each

$\$ .50$

$12 \mathrm{ft}$., each

1.50

PRUNUS PISSARDI-Beautiful purple foliage all summer.

4 ft., each.

$\$ .75$

$6 \mathrm{ft}$., each

1.50

RUSSIAN OLIVE-A small sized tree with silver white branches and foliage. Flowers small, yellow, very abundant in June, and have a most delightful perfume. The fragrance will reacn a distance of 100 yards. The foliage being white, contrasts beautifully with other trees. It should be in every garden. Prices:

3 to $4 \mathrm{ft}$, each...................................

4 to $5 \mathrm{ft}$, eacn.

.75

5 to $6 \mathrm{ft}$., each

\section{TAKE NOTICE}

We have generally on hand both larger and smaller trees and shrubs than those quoted in this Catalogue. We sell them at prices in proportion to their size and perfection. If you want such stock, write us, or come to the Nursery and see them.

TULIP TREE-A magnificent tree of the magnolia order, with beautiful tulip-like flowers.

3 to $4 \mathrm{ft}$. $\$ 1.00$

6 to $7 \mathrm{ft}$.

BLACK WALNUT-The well-known American walnut succeeds well here and makes a fairly rapid growth. Prices:

3 ft., each.................................................

5 ft., each..........................................

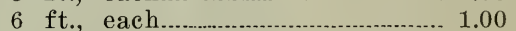

\section{WILLOW}

GOLDEN WILLO $N$-Beautiful orange and yellow branches in winter.

6 ft., each................................... \$ .50

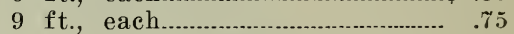

BLUE WILLOW-The branches in winter are sky blue and it contrasts fine with Golden Willow. Prices same as Rosemary Willow.

GOLDEN WEEPING WILLOW-A

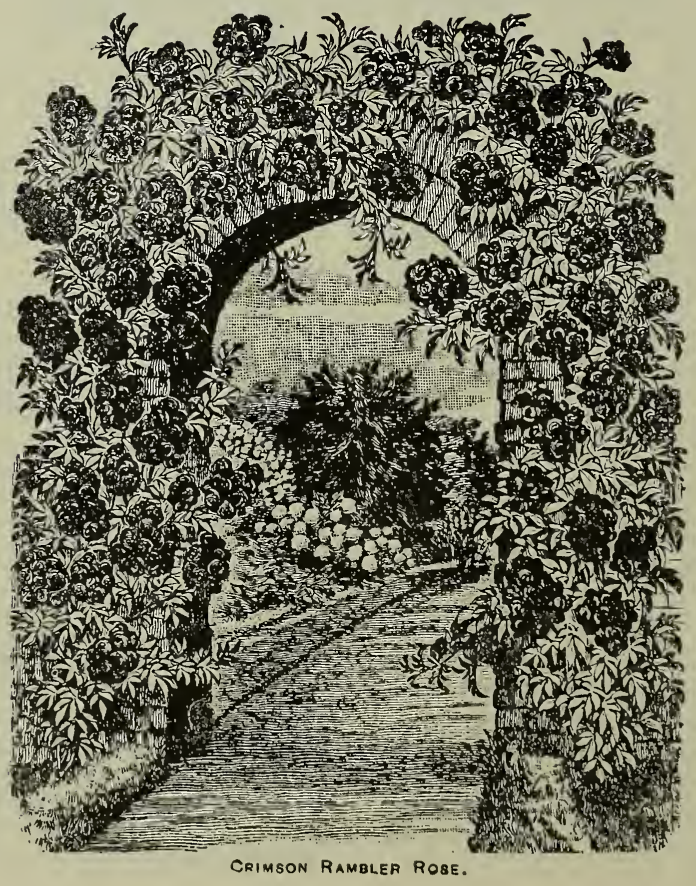


heautiful weeping tree with bright rellow bark.

ift., each.

$1:$ ft.. each.

1.00

1: ft., heary.

1.50

WISCONSIN WEEPING WILLOW-A very hardy, rapid grower, of large proportions. A nagnificent weeping tree for large space. Prices same as Golden Weeping Willow.

ROSEMARY WILLOW - The most beautiful of all Willows.

3 to $4 \mathrm{ft}$. $25 \mathrm{c}$

5 to $6 \mathrm{ft}$.

$50 \mathrm{c}$

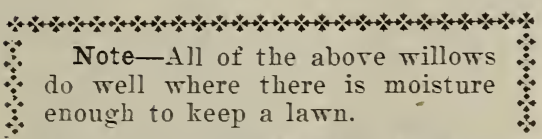

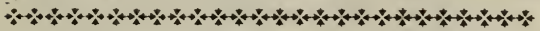

\section{EVERGREENS}

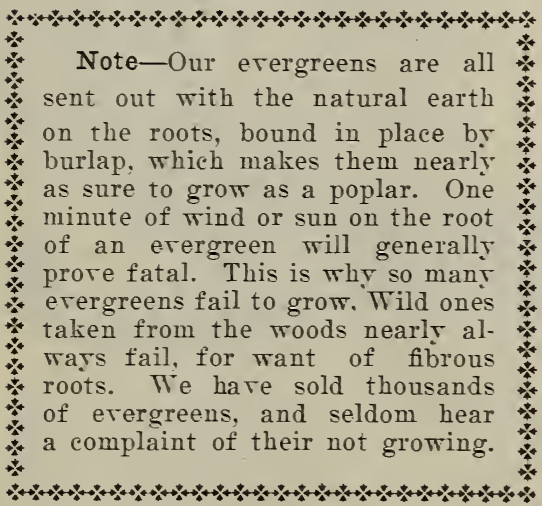

ARBORTITAE COMPACTA-A compact and upright form of Oriental arborvitae. It is a beautiful erergreen. Price:

2 ft., each.

$\$ .15$

3 ft., each

1.00

AMERICAN ARBORTITAE-

1 ft., each

$\$ .25$

$2 \mathrm{ft}$., each

$3 \mathrm{ft}$., each

.75

4 ft.. each

1.00

ARBORTITAE PYRAIIDALIS-Of upright growth, compact and very attractive; keeps its color well all winter. Prices:

$2 \mathrm{ft.}$, each

3 ft., each

1.50

$4 \mathrm{ft}$., each

2.50

SIBERIAT ARBORTITAE-Ter厂 compact, of globular shape, deep green. Makes an excellent hedge.

$2 \mathrm{ft}$., each.

3 ft., hearr, each

2.00
LA IVSON'S CYPRESS-This is one of the most beautiful of all evergreens; a rapid grower with beautiful featherr foliage, which retains its deep, rich green all winter.

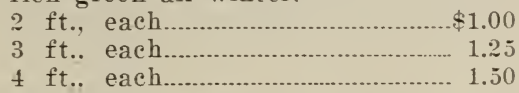

('HINESE JUNIPER-Foliage deep green and vers pretty. It grows much faster than the Irish Juniper. 2 ft.. each........................................ .75

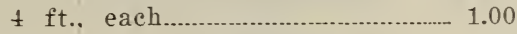

ENGLISH JUNIPER-A beautiful. fast-growing, compact, erergreen tree.

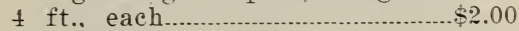

5 ft., each..................................... 3.00

IRISH JUNIPER-11/2 ft.. each...\$.50 $2 \mathrm{ft}$., each.................................... 1.00

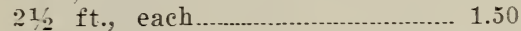

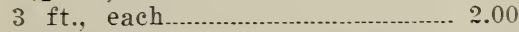

BLEE JUNIPER-From Japan; steelblue foliage; slender branches, with drooping habit.

$4 \mathrm{ft}$., each \$1.00

$5 \mathrm{ft}$., each

RED CEDAR - 4 ft.. each................ \$2.00 $5 \mathrm{ft}$, each..................................... 3.00

RETINISPORA PLUMOSA-A beautiful dwarf evergreen from Japan, with rers fine foliage and compact head. Prices:

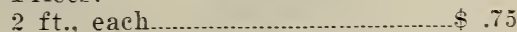

$3 \mathrm{ft}$. , each.......................................... 1.00

NORTII SPRUCE-3 ft., each....\$1.50 4 ft., each.................................... 2.00

BLACK SPRTCE-Leares dark green all the rear. Prices:

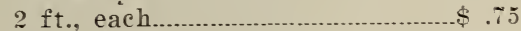

$3 \mathrm{ft}$, each........................................ 1.00

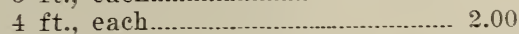

5 ft., each.......................................... 3.00

BLUE SPRUCE-The grandest evergreen of the earth; almost as blue as the sky. It grows in all shades from high steel blue to deep green. The high blue colored ones are scarce and expensive. Thes are rers hards. and stand transplanting well. Prices: Green forms, $1 \mathrm{ft.}$ each.............. \& .50 Green forms, 2 ft., each................ 1.00

\section{Blue Forms}

Blue forms, $1 \mathrm{ft..}$ each.................. 1.50 Blue forms, 11. $\mathrm{ft.}$. each.............. 3.00 Blue forms, $2 \mathrm{f}^{-} \mathrm{t}$.. each.................... 4.00

DITARE BOI-A fine dwarf erergreen plant, much used for edging. $1 \mathrm{ft}$. high. each.......................... \$ .25 Strong plants for edging:

Per 100

Per 1000, small 
MAHONIA AQUIFOLIA - A broad leaved evergreen shrub, with yellow flowers and blue berries. Foliage changes to rich purple and bronze in winter. Fine for the edges of shrubbery groups. It is very hardy and will do well in dry places. It should be largely planted. It is a dwarf grower, seldom more than three feet high. Price:

Strong plants, $1 \mathrm{ft}$., each..........\$ $\quad .25$

Strong plants, $2 \mathrm{ft.}$, each........... .50

Strong plants, $1 \mathrm{ft}$., per $100 \ldots . . . . .15 .00$

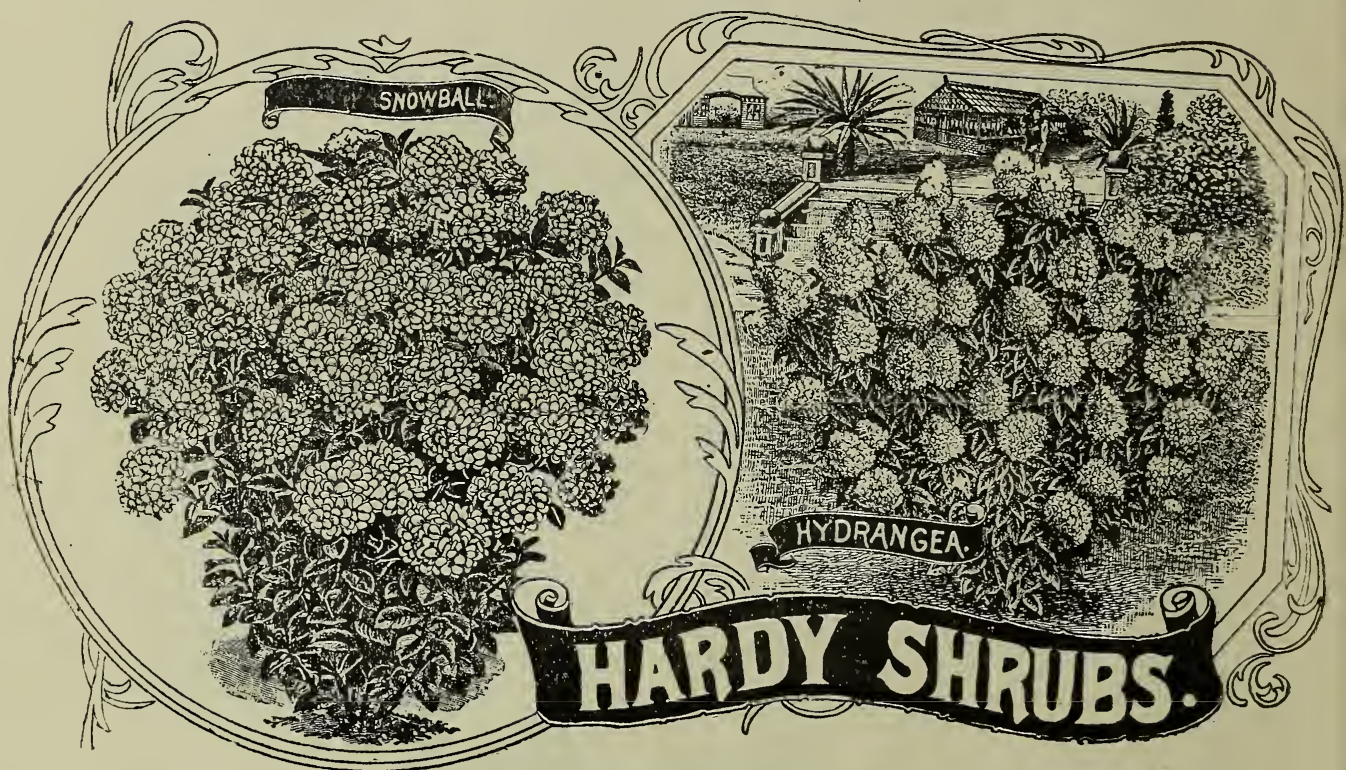

AMERICAN BARBERRY-Tery use. ful shrubs for ornament and hedge; foliage colors beautiful in autumn and the bright red berries are beautiful in winter.

$2 \mathrm{ft}$., each

$\$ .25$

Per 100 for hedge, small

5.00

PURPLE BARBERRY -A beautiful variety with constant purple foliage; yellow flowers, and red berries in winter.

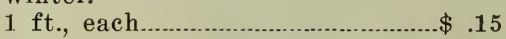

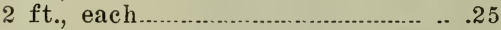

SCOTCH BROOM-From the Highlands of Scotland; deep green branches all winter and deep yellow flowers in summer.

$3 \mathrm{ft.}$. each

$\$ .25$

$5 \mathrm{ft}$, each.......................................... .50

$6 \mathrm{ft}$, each...................................... .75

BURNING BUSH-Beautiful in autumn for the color of their foliage and bright red and yellow berries.

$2 \mathrm{ft}$., each

$\$ .25$

$3 \mathrm{ft}$., each

.50

5 ft., each........................................ 1.00

Extra fine specimens................... 2.00

BLADDER SENNA-Yellow pea-shaped
Howers. followed by reddish pods or bladders; unique; blooms all summer.

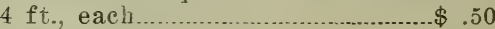

$6 \mathrm{ft}$., each 1.00

(ORNELIAN (HERRY-Useful for its showy, red berries and bright yellow. flowe1s in early spring.

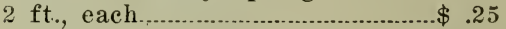

$4 \mathrm{ft}$, each.......................................... .50

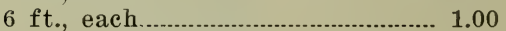

CORCHORUS-A valuable shrub with green branches, which produce very double orange yellow flowers from July to winter.

$3 \mathrm{ft}$., each.......................................... \$ .50

$5 \mathrm{ft}$., neavy and bushy, each....... 1.00

CRANDEL FLOIVERING CURRANTA new American black currant, ornamental as well as useful, large fruit and productive, very fragrant yellow flowers, foliage turns beautiful red in autumn.

$2 \mathrm{ft}$., each........................................ .25 $4 \mathrm{ft}$., each, from............... 50e to .75 according to perfection and bushiness of top.

FED FIOWERING CURRANT-Flow- 
ers bright red and beautiful leaves, and bush also fine. Price:

3 ft., each.

4 to $5 \mathrm{ft}$., each

$\$ .50$

1.00

CALYCANTHUS-Sweet scented wook and flowers; the fragrance is delightful. Price:

2 to $3 \mathrm{ft}$., each

$\$ .50$

$t$ ft.. each..........

1.00

DEUTZIA, PRIDE OF ROCHESTER and DOUBLE PINK-These are old and well known shrubs; very nice.

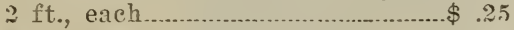

$4 \mathrm{ft}$., eacli....................................... .50

5 ft., heary, each........................ 1.00

RED DOGWOOD-Valuable for its bright red branches in winter and clusters of white fllowers in summer. $2 \mathrm{ft}$, each....................................\$. .35

IHITE FLOWERING DOGWOOD$3 \mathrm{ft}$, each..................................... \$ .50 5 t't., each....................................... 1.00

(TI-LEAF ELDER-Tery ornamental foliage and c్treat clusters of white Howers.

3 fit., each $\$ .25$

.5 ft, each
GOLDEN ELDER-Beautiful golden foliage all summer.

$3 \mathrm{ft}$., each $\$ .35$

$5 \mathrm{ft}$., each .75

FORSYTHIA - The earliest of all shrubs to flower; bright yellow flowers cover the branches in early spring.

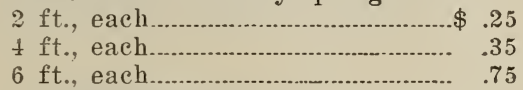

GOLDEN HOP - A large growing shrub or small tree, with very bright yellow leaves all summer. It is very attractive.

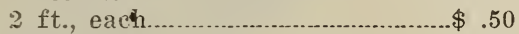

$4 \mathrm{ft}$. each..................................... 1.00

HYDRANGEA, P. G.-Very showy panicles of pink flowers in August; very hardy and valuable and sure to b]oom the first year. (See cut.)

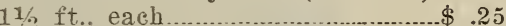

$2 \mathrm{ft}$, each........................................ 50

$3 \mathrm{ft}$. e erh..................................... .75

HIGH BUSH CRANBERRY-A very beautiful, hardy shrub which bears great clusters of bright red berries, fine for jelly; foliage colors beautiful in autumn.

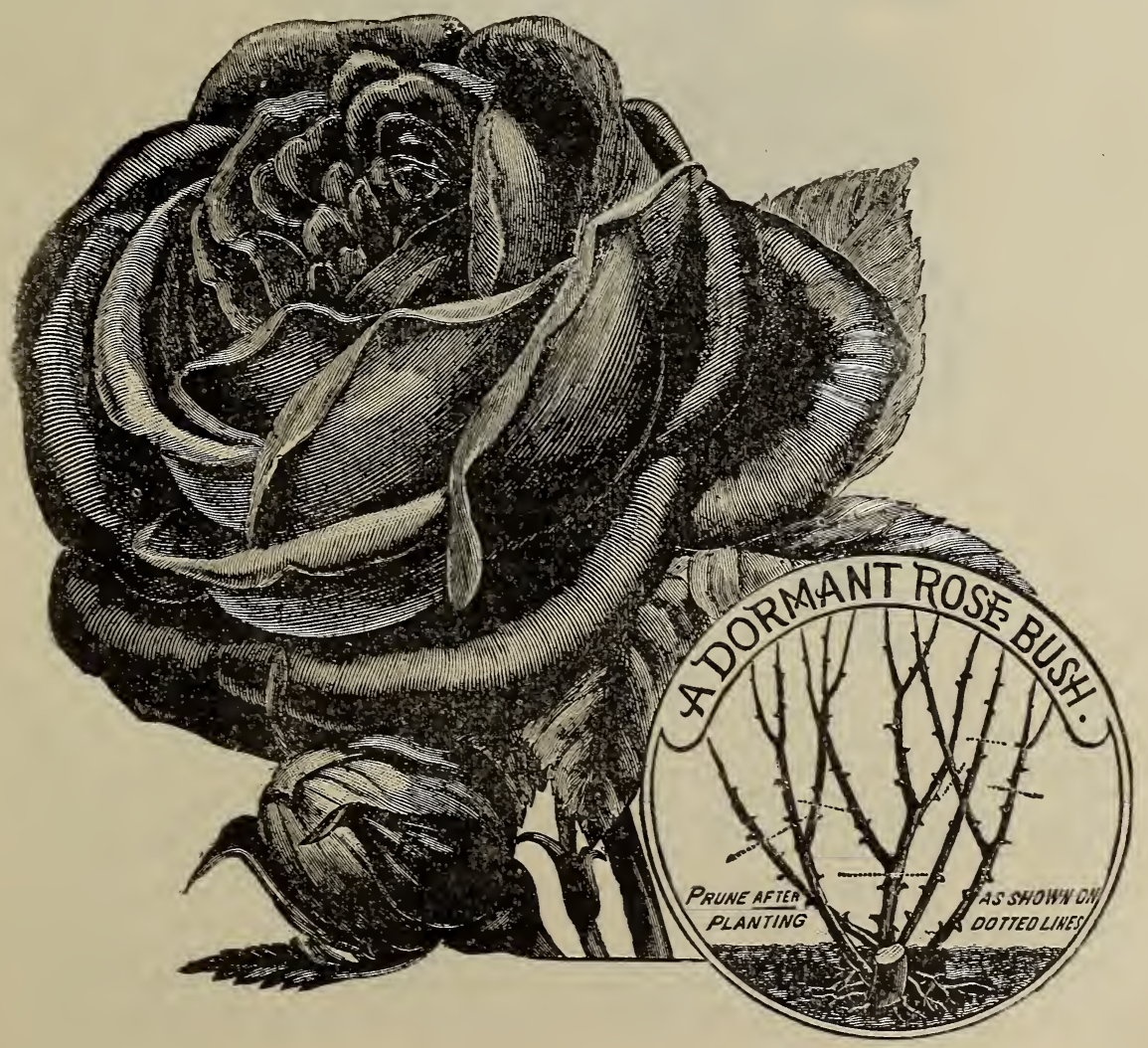


$2 \mathrm{ft}$., each.

$\$ .25$

$3 \mathrm{ft}$., each.

.50

$4 \mathrm{ft}$., each

.75

TARTARIAN HONEYSUCKLE-Often called Bush Honeysuckle; smothered in May with fragrant pink flowers; succeeds everywhere; fine to group with Spirear Vanhoutti, and makes a beautiful hedge.
Double White Lilac, each..75c to 1.00

Double Purple Lilac, each..75e to 1.00

PRIVET (English)-Largely used for ornamental hedges.

1 to $2 \mathrm{ft}$., per 100

PURPLE FRINGE-A very ornamental large shrub from Europe. Its dense, fringe-like flowers appear in July and remain for months.

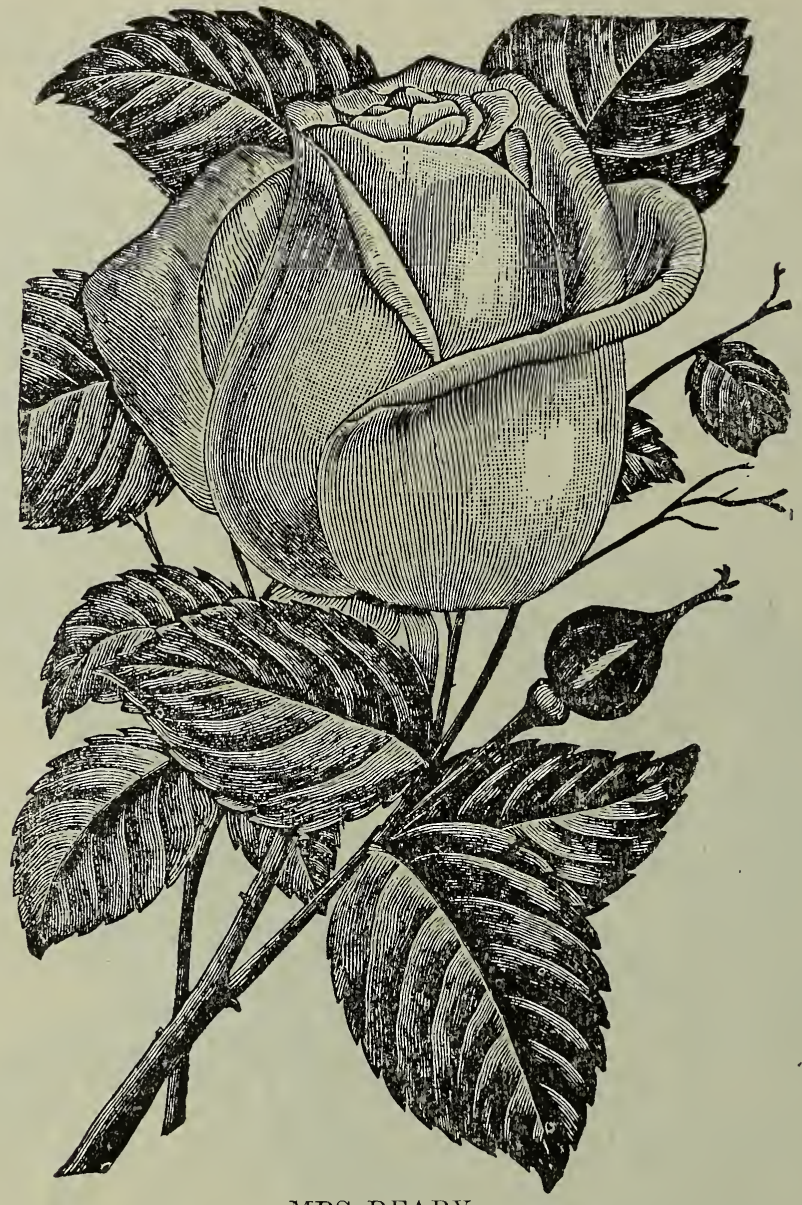

MRS PEARY

2 ft., each.

$\$ .25$

$3 \mathrm{ft}$., each

.35

4 ft., each.

.50

$5 \mathrm{ft}$, heavy, each................. $75 \mathrm{c}$ to 1.00

1 to $2 \mathrm{ft}$., for hedge, per $100 \ldots \ldots 10.00$

\section{LILAC}

LILA ('S-White-2 ft., each.......... .25

PURPLE-3 ft., each...................... . .35

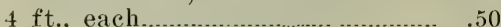

5 to $6 \mathrm{ft}$ extra fine.............. $75 \mathrm{c}$ to 1.00
$3 \mathrm{ft}$., each

$\$ .25$

$4 \mathrm{ft}$. , bushy, each...

5 to $6 \mathrm{ft}$., extra fine

JAPAN QUINCE--Very bright scarlet flowers early in spring; very fine.

2 ft., each.

$\$ .25$

$3 \mathrm{ft}$., each.

.50

SNOWBERRY - A medium sized shrub which bears in great profusion prettv snow white berries that hang on all 
winter; contrasts beautifully with burning bush back of it. Price:

$\therefore$ ft.. each $\$ .35$

ift., each .50

\section{SUMAC}

('IT LEAF SUMAC-Beautiful foliage, resembling immense ostrich plumes.

2 to $3 \mathrm{ft}$., each $\$ .50$ $t$ to $5 \mathrm{ft}$., each. 1.50

ATAGHORN SUMAC-A small tree with large pinnate foliage and bunches of red berries in autumn. Leares color red after frost.

+ ft., each. $\$ .25$

j ft., each .50

\% ft. each 1.00
SPIREAR PLUMOSA (or White Bean Leaf Spirear,-Immense pinnacles of beautiful cream-colored flowers, blossoms in July, when most other flowering shrubs are out of bloom. It thrives well everrwhere and should be in every garden. Price:

3 to $4 \mathrm{ft}$., each. $\$ .50$

t to $5 \mathrm{ft}$., each. 1.00

SPIREAR VANHOUTTI-The best spirear in cultivation; when in bloom looks like a bank of snow; gives a lovely effect when planted in groups with Tartarian Bush Honersuckle at the back of it, contrasting the pink and white flowers.

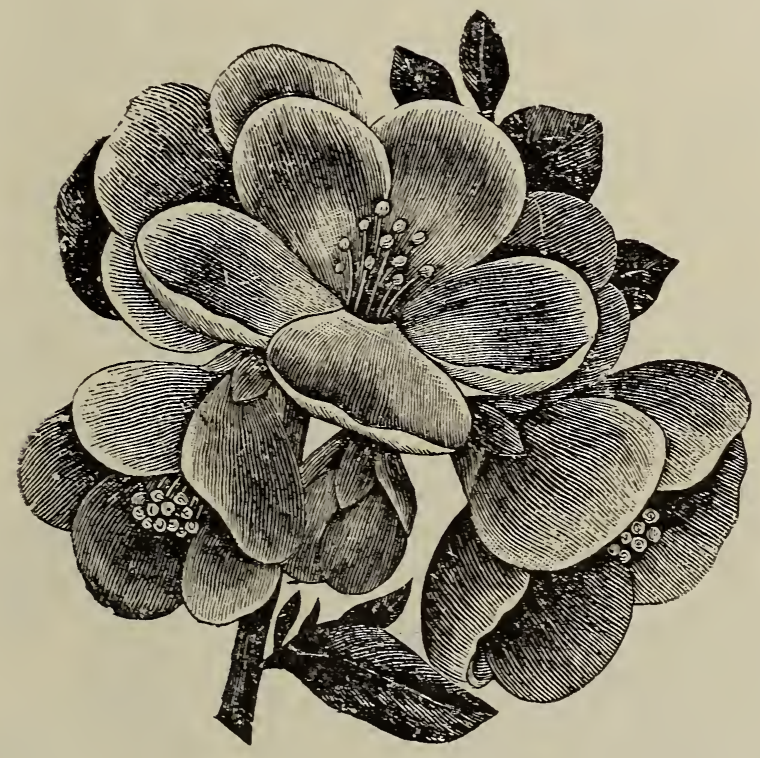

JAPAN QUINCE-Red Flowered

SIRINGA (Grandiflora)-From Japan; much larger and finer than our native liind.

3 ft., each...............................................

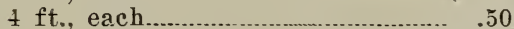

5 ft., extra, each......................... 1.00

SNOTWBLL-2 ft., each ................. \$ .35

$3 \mathrm{ft.}$, each.......................................... .50

$4 \mathrm{ft}$. , each................................ $75 \mathrm{c}$ to 1.00

DOUBLF FLOWERED SYRINGA-. Like other syringas, but has beautifu] white double flowers. Price:

3 to $4 \mathrm{ft}$., each

GOLDEN SPIREAR-Beautiful golden foliage, contrasts fine with purple foliage or blue flowers. Price:

3 to $4 \mathrm{ft}$., each.

4 to $5 \mathrm{ft}$. each 1.00
2 ft., each. $\$ .25$

$3 \mathrm{ft}$. , each............................................ .3j

$4 \mathrm{ft.}$, each............................................... .50

$5 \mathrm{ft}$., extra fine and bushy tops, each $75 \mathrm{c}$ to 1.00

BRIDAL WREATH-The true Bridal Wreath Spirear, with long, curring branches closely set with small roselike double white flowers. Exceedingly pretty and chaste. Succeeds well everywhere; evervone should have it. Price: 3 to $4 \mathrm{ft}$., each....\$1.00

VIBURNUM (Lantana Leared)Shrubs of the Snowball family, with beautiful white flowers, showr black berries and beautiful foliage; should be in every garden.

$3 \mathrm{ft}$, each. $\$ .35$ 
$4 \mathrm{ft}$. , each

.50

WIGELIA ROSEA-A beautiful shrub flowering in June, with fragrant, deep pink flowers; makes a gorgeous effect when planted in oroups with Syringa krandiflara at the back of it. $2 \mathrm{ft}$., each. .$\$ 35$

$3 \mathrm{ft}$., each. .50

$4 \mathrm{ft}$, each.

.75

$5 \mathrm{ft}$., each. 1.00

\section{CLIMBING VINES}

AMERICAN IVY (Virginia Creeper)One of the most popular of all climbers. Each. $25 \mathrm{c}$ to $50 \mathrm{c}$

BOSTON IVY (Ampelopsis Veitchi)Fine for covering walls; foliage changes to brignt crimson and yellow in antumn. Needs protection in winter the first year or two; after that it is hardy.

strong two-year roots.

$50 \mathrm{c}$

BITTER SWEET-A rapid growing twining vine with bright red berries all winter; very desirable where it can twine. Price:

3 to $4 \mathrm{ft}$., each...

$50 \mathrm{c}$

CLEMATIS JACKMANNI-Beautiful large royal purple flowers 4 inches across. Two-year, each...................50e

CLEMATIS PANICULATA-From Japan; new and very fine; white, fragrant flowers in September.

2 year, each. $50 \mathrm{c}$

ENGLISH IVY-The well-known evergreen ivy of England; succeeds best on the north side of bnilding.

Price, each
HALL'S JAPAN HONEYSLCKLE (Evergreen Sweet Scented Honeysuckle)-Fine for covering rocks, stumps, etc.; flowers white and yellow; very sweet. Price:

2 ft., each. 25e:

$4 \mathrm{ft}$, each........................................

MONTHLY HONEYSUCKLE-The best. honeysuckle in cultivation; blooms nearly all summer; flowers white, rect and yellow; very fragrant.

1 year, each.

$25 c$

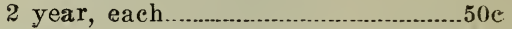

SCARLET TRU M P E HONEYSUCKLE-Brilliant scarlet flowers; fine.

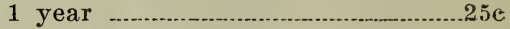
2 year .................................................. 00

WISTARIA MAGNIFICA-The grandest one of the species; a great climber with long strings of beautifuI blue flowers.

Price, strong roots, each.................50

TRUMPET CREEPER-Fine for rocks and trees, large orange scarlet flowers. Each ..................................

PAEONIAS-Three varieties: white, red and pink, each ......................... Four for .............................. 1.00

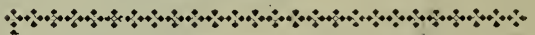
* In this list of trees and shrubs, * where there is a difference in * price, it is for different sizes and * qualities. The highest are gen* erally for fine, large, perfect * specimens, but all are good and wil be found much better than * Eastern stock.

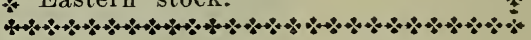

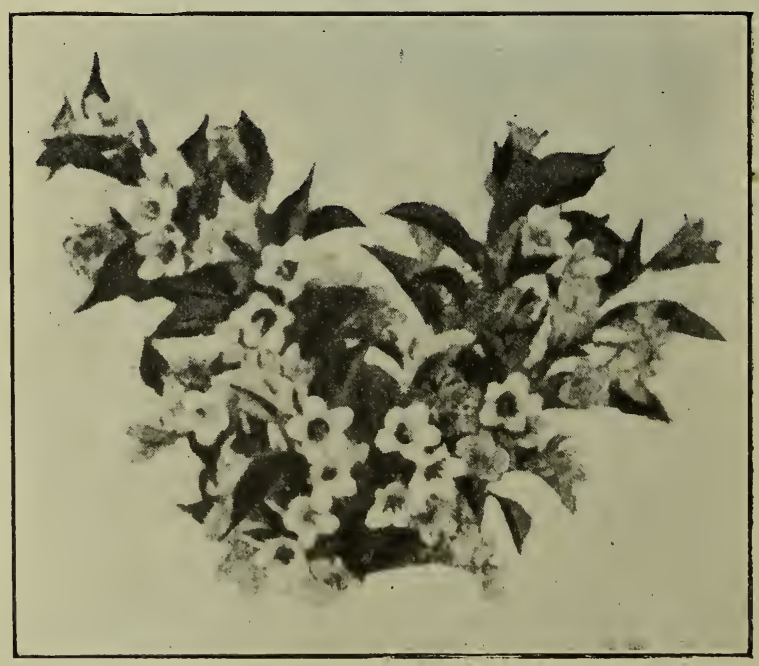

NOTE--Where extra fine specimens of trees and plants are selected, they will be subject to special prices. 


\section{ROSES}

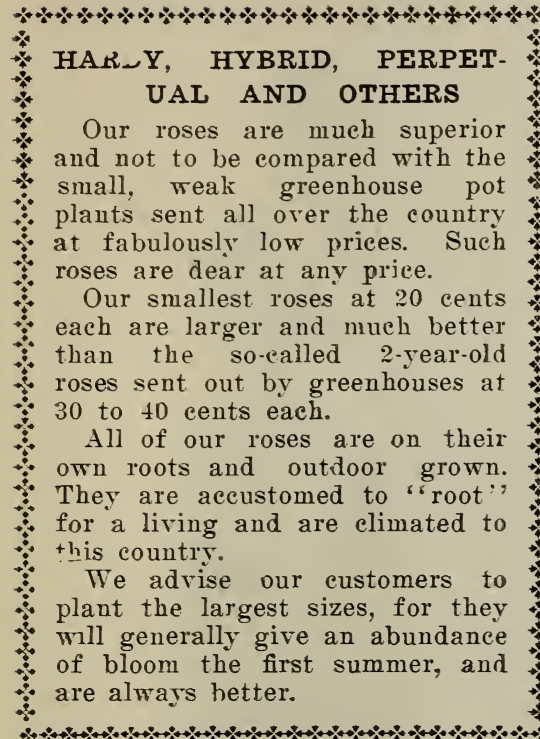

\section{VARIETIES OF ROSES}

The following list eontains the best, selected from over 300 kinds which we have tested. They are the gems of haldy roses.

\section{PRICES OF ROSES}

First size, A1, each........................... . . +0 3 for 1.00

Second size, each.................................. 4 for 1.00

Third size, each.

All the roses in the following list are perpetual bloomers except Pink Moss and Crimson Rambler.

\section{VARIETIES OF ROSES}

BABY RAMBLER-Flowers much like Crimson Rambler, bright red; bush dwarf and compact, and blooms continuously tnroughout the season. It is fine; don't miss it.

CAROLINE TESTOUT-Blooms all the time, very large flowers, deep shell pink.

GENERAL JACQUEMINOT - Bright erimson searlet; probably the most popular hardy rose.

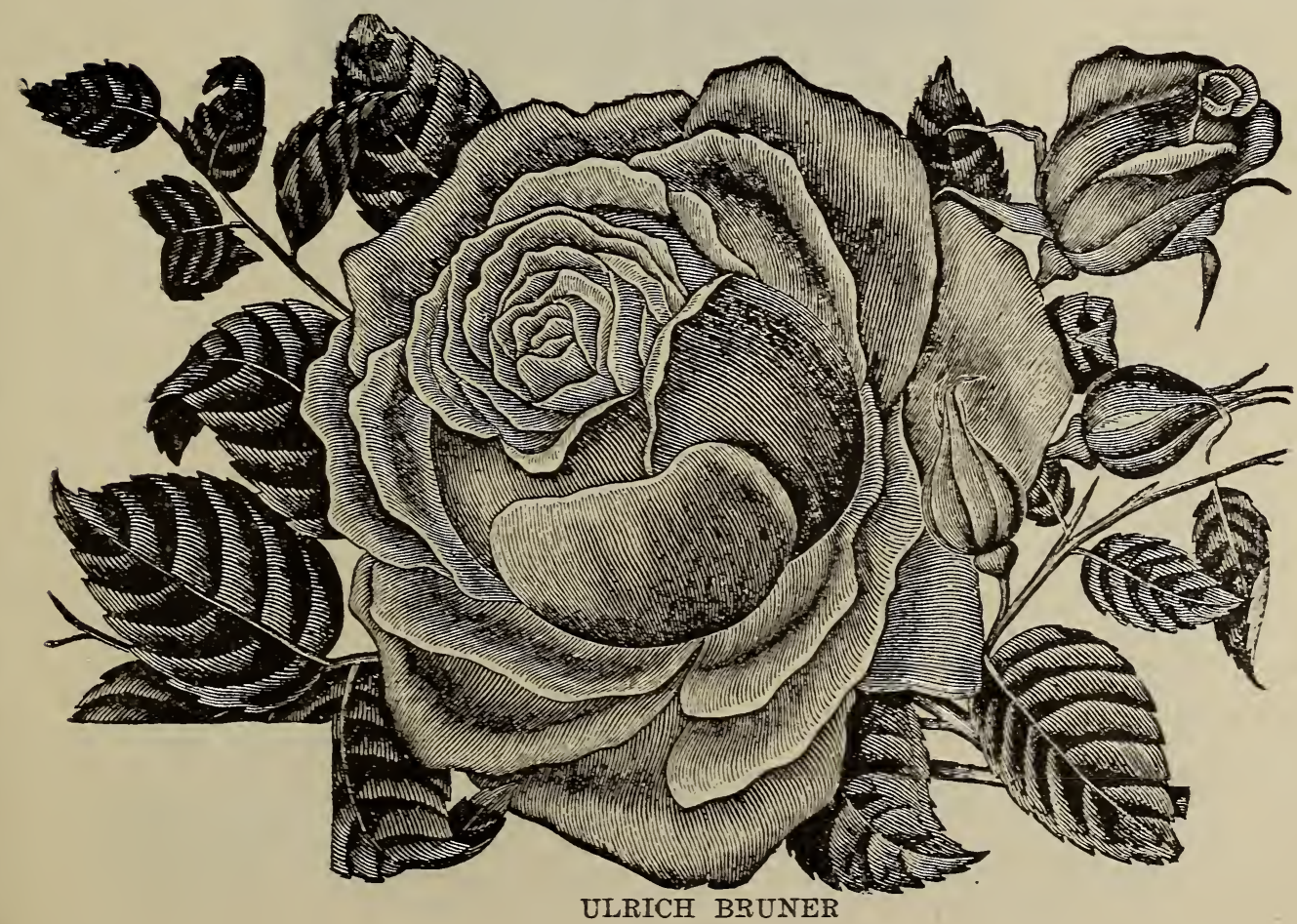




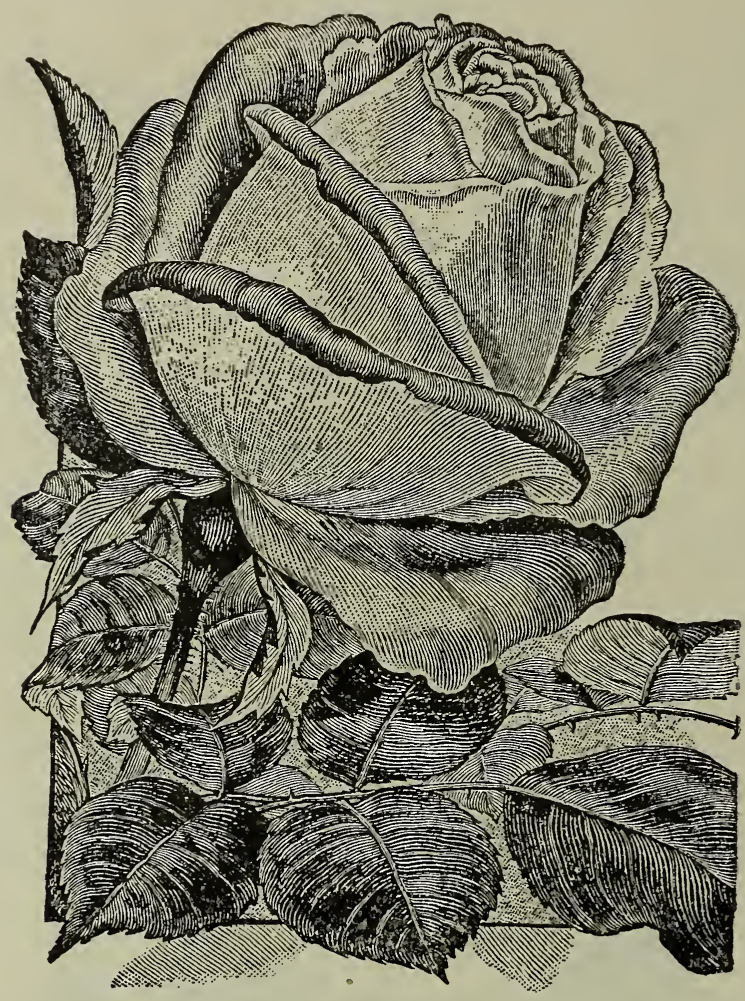

LA FRANOE

KAISERINE AUGUSTA VICTORIAA beautiful rose with elegant, large pointed buds and very large, full double flowers. Color pure ivory white.

LA FRANCF-Beautiful peach blossom color, immense buds, very fragrant. (See cut.)

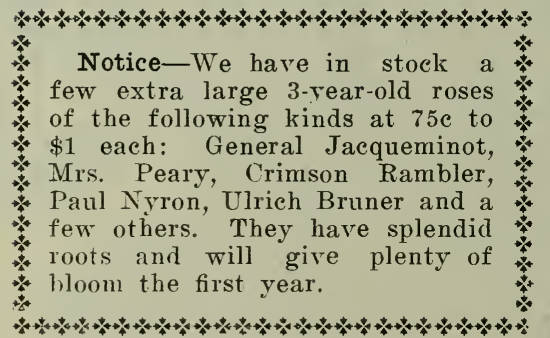

MARSHAT, P. WILDER-Very double, rich scarlet crimson; nearly always in hloom.

PACL NEYRON-Probably the largest rose in cultivation; shell pink.
PRINCE DE ROHAN-Rich scarlet maroon, very fine.

PINK MOSS-Large, verv double pink flowers.

ULRICH BRUNER-Brioht rosv re:l superb buds; none better. (See cut.)

VISCOUNTESS FOLKSTONE-Fxquisite creamy pink color; beautiful buds, excellent.

VIRGINIA R. COX-Color fiery crimson, with a dark velvety sheen, very fragrant. the freest blooming rose in existence. The mass of color produced is wonderful, and the handsome foliage adds materially to its beauty as a bedding rose. A queen among garden roses.

WINNIE DAVIS-A fine new American pedigreed rose, raised by a cross between the famous Kaiserine Augusta Victoria and Belle Siebrecht. Color rich apricot pink, shaded to flesh at base i petals. Beautifullly formed buds and flowers. 


\section{CLIMBING ROSES}

CRIMSON RAMBLER-The most gorgeous of all climbers, bright scarlet, in clusters. (See eut.)

MRS. PEARY-Immense white buds and beautiful flowers, equal to hothouse roses; the grandest white rose ret produced. (See cut.)

Price, each $50 \mathrm{c}$
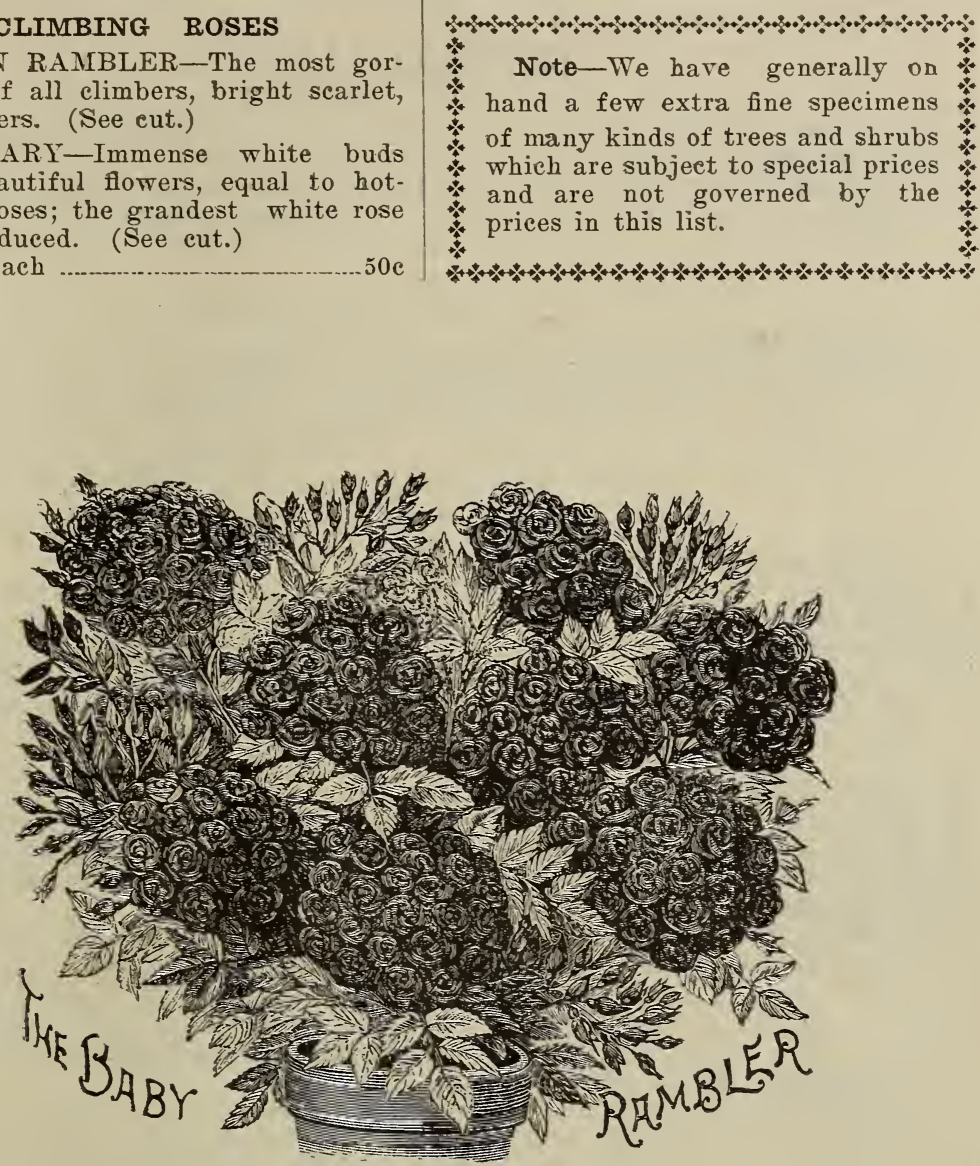

\section{REFERENCES}

As to our responsibility, the quality and the genuineness of our stock, we refer to any of the following parties: Traders National Bank, Spokane.

John A. Finch, of Finch \& Campbell, Spokane.

Frank H. Graves, the well-known and eminent lawyer, Spokane.

Holley-Mason Hardware Co., hardwaro merchants, Spokane.

George Farwell, Wenatchee, Wash.

George A. Sonnemann, mining expert, The Rookery, Spokane.

J. F. Strong, fruit grower, P. O, Spokane.
John Stirns, farmer, Reardan, Wash.

R. Kiesling, fruit grower, Moran Prairie, P. O. Spokane.

John T. Ellsasser, fruit grower, Sand. point, Idaho.

Jim Shoemaker, farmer, Reardan, Wash.

James Newhouse, farmer, Springdale, Wash.

Evergreen State Fruit Co, P. O. Spokane.

The Evergreen State Fruit Co.'s orchards are among the largest in the Northwest, and the company buys of us largely every year. Just ask them what they think of our stock. 


\section{TESTIMONIALS}

R. A. Jones, Spokane, Wash.

Wilson Creek, Wash.

The trees I got of you last spring did fine; made a good growth and never lost but five trees out of 115 .

Yours, truly, JOHN' LINEBAUGH.

R. A. Jones, Spokane, Wash.

White, Idaho, January 29, 1906.

Dear Sir: Will you please send me a new catalogue of fruit trees, as I have lost my old one. The trees I got from you last spring did the best of any trees 1 ever saw planted the first year, so I am going to order some more this spring. Respectfully, CHARLEY E. OLESON.

R. A. Jones, Spokane, Wash.

Leahy, Wash., January 3, 1906.

Dear Sir: Will you please send me your prices on one and two year old fruit and shade trees? My mother, Mrs. MeCanna, planted a lot of your trees here last spring which are doing well. Only five in the lot died.

Yours respectfully,

T. J. Me $A$ ANNA.

Mr. R. A. Jones, Riverside Nursery, Spokane.

Spokane, Wash., February 5, 190\%.

Three years ago I bought from you 1000 3-year-old apple trees. These were set out on my ranch at Greenacres, and all lived and flourished. They are strong, thriving, hearty trees, and I am glad that I bought the 3-year-old rather than a younger tree.

I believe it would not have been possible to set out apple trees which would have been more successful than these.

Very tiuly yours,

F. W. DEWART.

R. A. Jones, Hillyard, Wash.

Deer Park, Wash., October 20, 190\%.

Dear Sir: I write you to let you know that out of the 850 trees I receired from you last spring I only lost 10 trees and the rest made a fine growth and are nice trees. I got a shipment of trees from Galbraith Nurseries of Fairbury, Neb., and they were condemned by the inspector here at Deer Park and I have as yet been unable to get anything out of them

$$
\begin{aligned}
& \text { Yours very truly, } \\
& \text { HENRY ROBERTS. }
\end{aligned}
$$

R. A. Jones, Spokane, Wash.

Sandpoint, Idaho, May 11, 1906.

Dear Sir: I have received the fruit trees in good order and am rell satisfied with the trees.

Yours trulr,

MATH. SCHWENK.

Palouse, Wash., Norember 24, 1908.

R. A. Jones, Riverside Nurseries, Spokane, Wash.

Dear Sir: My bill of trees are at hand and all O. K. Must say they are positively without exception the finest lot of trees I ever saw.

Yours truly,

FRED R. VOWELL.

R. A. Jones, Spokane, Wash.

Orient, Wash., April 16, 1906.

Dear Sir: I receired the trees in good order. The trees are looking good, and I will get some more next spring.

Yours truly,

İ. LARSEN. 
R. A. Jones, Spokane, Wash.

Ellensburg, Wash., April 15, 1906.

Sir: I received the trees yesterday morning in good shape and Mr. Maxey, the fruit inspector, examined them and pronounced them all $O$. K. and said they were the finest lot of trees ever sent to this valley. I am well pleased with them. I will start to setting them out tomorrow. I expect to order as many more next year. Enclosed find draft for $\$ 20.70$, for which give me credit and send me a receipt in full and oblige

W. J. PEED.

R. A. Jones, Riverside Nursery, Hillyard.

R. F. D. No. 1, Hayford, March 30, 1906.

Dear Sir: My trees came to hand yesterday all in fine condition except the four wild plums; these have not been sent. Please forward as soon as possible, also my account, duly receipted, and oblige.

I have had considerable experience with fruit trees, and I have never seen better stock or finer roots anywhere. I shall certainly order further supplies from you next spring. I am highly pleased with the trees you have sent me, and they were packed perfectly and arrived in grand condition.

Yours faithfully,

F. D. PHILLIPS.

R. A. Jones, Spokane, Wash.

Reardan, Wash., April 23, 1908.

Dear Sir: I receired your consignment of shrubs and plants today. Ther were in fine shape and we will plant them soon. The paeonias were very nice.

MRS. FLORA HARTMAN.

R. A. Jones, Spokane, Wash.

Cheney, Wash., May 11, 1908.

Dear Sir: I set out, last fall, twenty-five of your pear trees, twenty-five cherry and six plum trees. Every one of these trees are looking fine.

Yours,

H. R. RIST.

R. A. Jones, Riverside Nursery, R. D. 1, Hillyard, Wash.

Spokane, Wash., April 13, 1908.

Dear Sir: I thank you for your prompt delivery and am rery much pleased. with the stock. It was all in splendid condition.

Yours truly,

F. P. GREENE.

R. A. Jones, Spokane, Wash.

Crescent, Wash., May 1, 1909.

Dear Sir: The package of trees, ete., you shipped on April 21 finally reached me on the 29 th, eight days on the road, but had been so well packed that they were still in good condition. Respectfully,

E. E. EMERY.

R. A. Jones, Spokane, Wash.

Wapato, Wash., Dec. 1, 1908.

Dear Sir: Your lot of dewberries received all O. K., and I found them to be the finest and best rooted plants $I$ ever saw; also the fruit trees I received from your nuisery last spring were equally as good, as they made wonderful growth, some as high as five feet, and all alive and thriving fine. I have recommended your nursery stock to my neighbors. Many thanks for the good stock I have received from you

M. D. MONTGOMERY.

R. A. Jones, Spokane, Wash.

Sterensville, Mont., Feb. 6.

Dear Sir: As I expect to get about 100 cherry trees-the Bing-and some McIntosh Red apples, I wish to get your price list before I make my selection. I got trees from your place three or four years ago, and they were fine trees. Please send me prices of sweet cherry trees.

Respectfully,

CHARLES FOUST.

Weippe, Idaho, April 26, 1908.

R. A. Jones, Spokane, Wash.

Dear Sir: We receired trees all right and in good order. Also the money sou sent back. Thank you, and much obliged.

EVA YANTZIS. 
Mr. Jones, Hillyard, Wash.

Miea, Wash., Feb. 24, 1909.

Dear Sir: I bought a bill of trees of you last year and they were very satisfactory, indeed. I want more this spring. Will you kindly send me yourcatalogue and oblige me?

Very respectfully yours,

E. W. DOBSON.

Riverside Nursery, Spokane, R. A. Jones, Prop.

Woodland, Idaho, Feb. 9, 1910.

Dear Sir: Please send me your catalogue and prices, as I will want some of your trees. Some years ago I got some of your trees, and they were the: best I ever saw and are doing fine.

Yours truIy,

J. L. JOHNSON.

R. A. Jones, Spokane, Wash.

PuIlman, Wash., March 15, 1909.

Send me your catalog. Last year we proved the truth of your advertisement in the Review. We bought about two dozen trees and shrubs and every: one grew.

Very respectfally,

MRS. G. H. McCROSKEY.

R. A. Jones, Hillyard, Wash.

Medimont, İdaho, April 17, 1909.

Dear Sir: Trees arrived in good condition. They have fine roats, and are better than any others I have seen delivered here. Yours truly, JOEL 'JOHNSON.

R. A. Jones, Spokane, Wash.

Libby, Mont., May 3, 1909.

Dear Sir: The order of trees received a few days ago in the rery best of condition, and I am more than pleased with the quality of the stock. Such nice straight trees, with such roots, cannot be improved upon; and also I wish to thank you for your extreme care in packing. I shall want more nurserystock from time to time, and you can count on my future orders.

I remain respectfully yours,

EDWIN C. CHAPMAN.

R. A. Jones, Spokane, Wash.

Clagstone, Idaho, June 15, 1908.

Dear Sir: Those 109 Tartarian Honeysuckles we got from you two years ago are all alive and simply glorious this spring. Yours very truly,

PAUL CLAGSTONE.

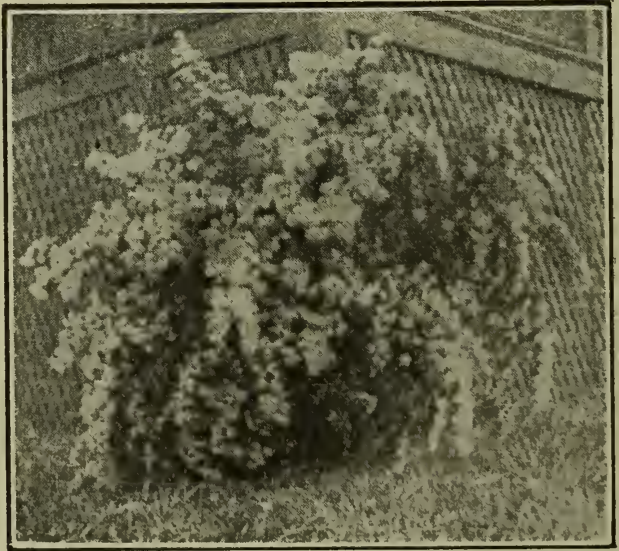

SPIREAR VANHOUTTI 


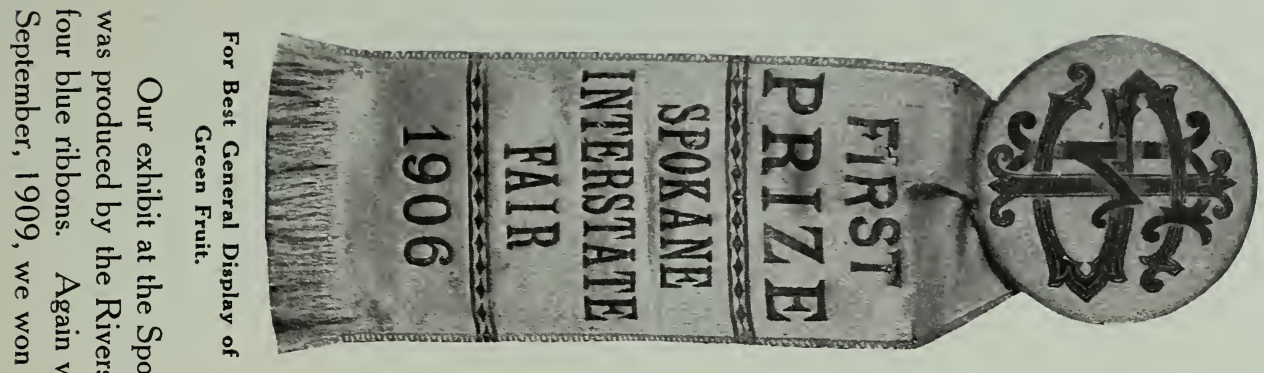

9 D

इ

จุ

으으ㅇㅡㅡ

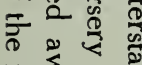

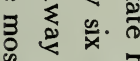

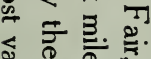

¿

ㅇำ

ㅇํㅇ

ก ๑ : ญ

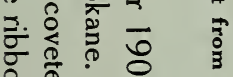

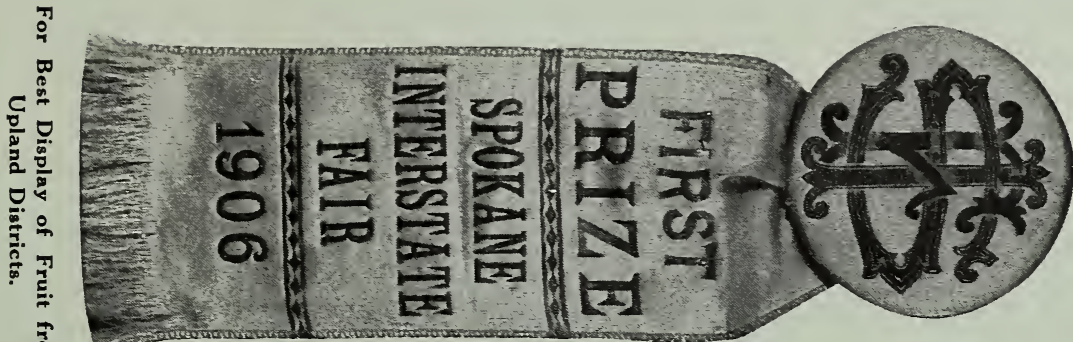

ฉ

ㄱ. @

क

$\approx$ 둥

훙

$\omega \cong$

융 훙

ㄷ.

จ

핑.

क क N

ข

T) 율

․ ำ

₹

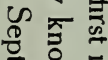

$3 \leqq 3$

จ क ख

б) ลे

ㄴ.

矛

$\geq \stackrel{2}{2}$

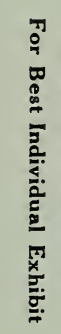

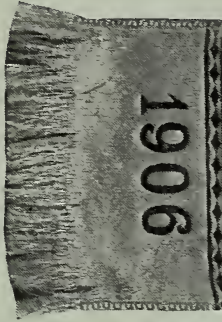
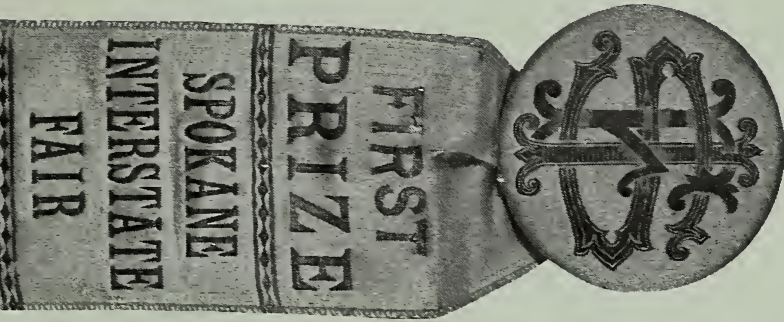

ㄱ. 훙 을
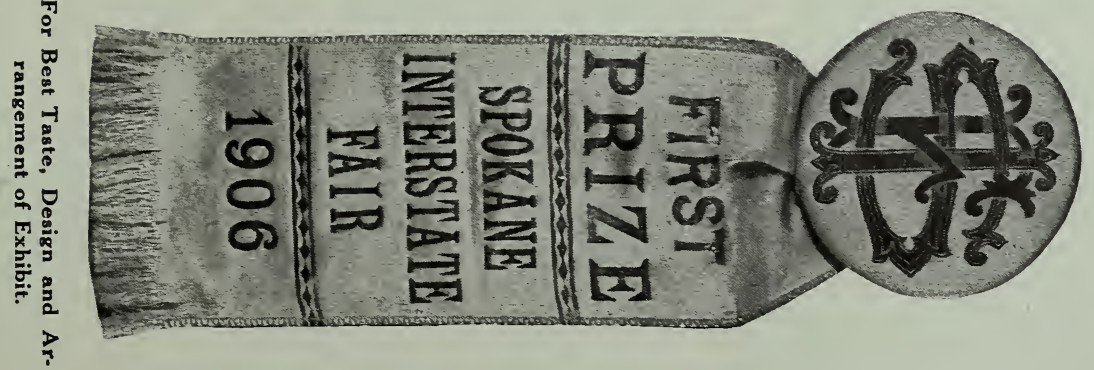


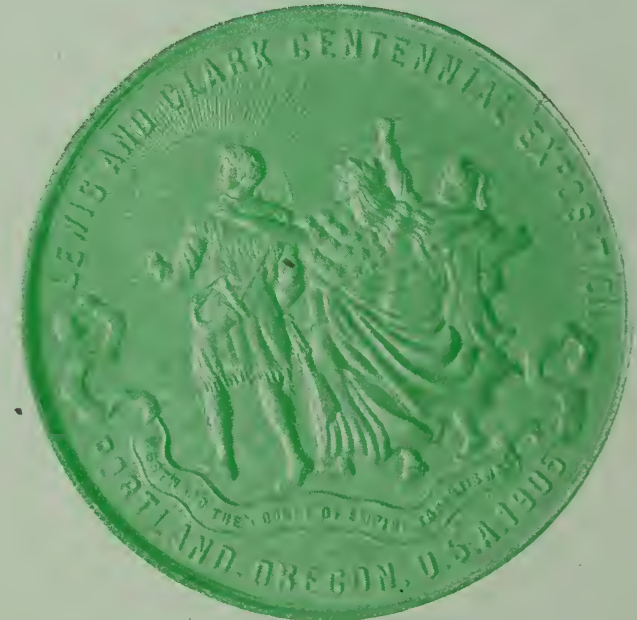

The above Gold Medal was awarded to us by the Lewis and Clark Exposition at Portland, Oregon, in 1905 for best Peaches. These Peaches were grown by the Riverside Nursery, siz miles from Spokane. 